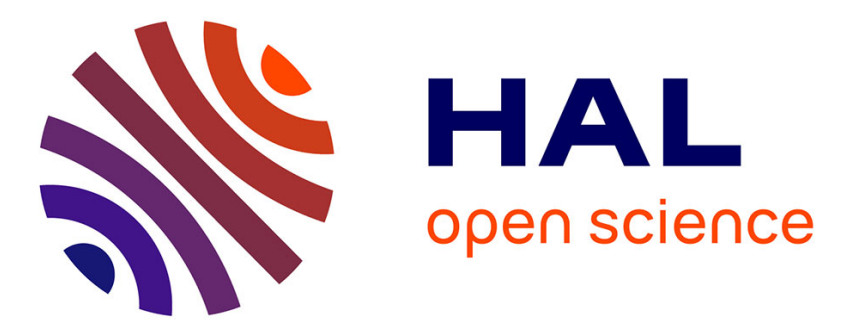

\title{
Enzymatic Construction of Artificial Base Pairs: The Effect of Metal Shielding
}

Marie Flamme, Fabienne Levi-Acobas, Susanne Hensel, Shuvankar Naskar, Pascal Röthlisberger, Ivo Sarac, Gilles Gasser, Jens Müller, Marcel Hollenstein

\section{- To cite this version:}

Marie Flamme, Fabienne Levi-Acobas, Susanne Hensel, Shuvankar Naskar, Pascal Röthlisberger, et al.. Enzymatic Construction of Artificial Base Pairs: The Effect of Metal Shielding. ChemBioChem, 2020, 10.1002/cbic.202000402 . pasteur-02928354

\section{HAL Id: pasteur-02928354}

https://hal-pasteur.archives-ouvertes.fr/pasteur-02928354

Submitted on 2 Sep 2020

HAL is a multi-disciplinary open access archive for the deposit and dissemination of scientific research documents, whether they are published or not. The documents may come from teaching and research institutions in France or abroad, or from public or private research centers.
L'archive ouverte pluridisciplinaire HAL, est destinée au dépôt et à la diffusion de documents scientifiques de niveau recherche, publiés ou non, émanant des établissements d'enseignement et de recherche français ou étrangers, des laboratoires publics ou privés.

\section{(ㅇ)(1) $\$$}

Distributed under a Creative Commons Attribution - NonCommerciall 4.0 International 


\title{
Effect of metal shielding on the enzymatic construction of artificial base pairs
}

\author{
Marie Flamme ${ }^{1,2,4}$, Fabienne Levi-Acobas ${ }^{1}$, Susanne Hensel ${ }^{3}$, Shuvankar Naskar ${ }^{3}$, Pascal \\ Röthlisberger $^{1}$, Ivo Sarac $^{1}$, Gilles Gasser ${ }^{4}$, Jens Müller, ${ }^{3}$ and Marcel Hollenstein ${ }^{1 *}$ \\ ${ }^{1}$ Institut Pasteur, Department of Structural Biology and Chemistry, Laboratory for Bioorganic Chemistry of \\ Nucleic Acids, CNRS UMR3523, 28, rue du Docteur Roux, 75724 Paris Cedex 15, France \\ ${ }^{2}$ Université Paris Descartes, Sorbonne Paris Cité, 12 rue de l'École de Médecine, 75006 Paris, France \\ ${ }^{3}$ Westfälische Wilhelms-Universität Münster, Institut für Anorganische und Analytische Chemie, Corrensstr. 30, \\ 48149 Münster, Germany \\ ${ }^{4}$ Chimie ParisTech, PSL University, CNRS, Institute of Chemistry for Life and Health Sciences, Laboratory for \\ Inorganic Chemical Biology, 11, rue Pierre et Marie Curie, 75005 Paris, France
}

\section{ABSTRACT}

Formation of metal base pairs is a versatile method for the introduction of metal cations into nucleic acids that has been applied in numerous applications including the construction of metal nanowires, development of energy, charge transfer devices and expansion of the genetic alphabet. As an alternative, enzymatic construction of metal base pairs represents an alluring strategy that grants access to longer sequences and offers the possibility of using such unnatural base pairs (UBPs) in SELEX experiments for the identification of functional nucleic acids. This method remains rather underexplored and a better understanding of the key parameters in the design of efficient nucleotides is required. Herein, we have investigated the effect of methylation of the imidazole nucleoside $\left(\mathbf{d I m}^{\mathbf{n M e}} \mathbf{T P}\right)$ on the efficiency of the enzymatic construction of metal base pairs. The presence of methyl substituents on $\mathbf{d I m T P}$ facilitates the polymerase-driven formation of $\mathbf{d I m}^{4 \mathbf{M e}_{-}} \mathrm{Ag}^{\mathrm{I}}-\mathbf{d I m}$ and $\mathbf{d I m}{ }^{2 \mathrm{Me}} \mathbf{T P}-\mathrm{Cr}^{\mathrm{III}}-\mathbf{d I m}$ base pairs. Steric factors rather than basicity of the imidazole nucleobase appear to govern the enzymatic formation of such metal base pairs. We also demonstrate the compatibility of other metal cations rarely considered in the construction of artificial metal base with enzymatic DNA synthesis under both primer extension reaction and PCR conditions. These findings open up new directions for the design of nucleotide analogs for the development of metal base pairs. 


\section{Introduction}

The expansion of the genetic alphabet via the creation of additional, unnatural base pairs (UBP) is a long-standing goal in synthetic biology. Many artificial base pairs have been designed in the past decade, mainly based on hydrogen bonding, ${ }^{[1]}$ shape complementarity ${ }^{[2]}$ or hydrophobic interactions. ${ }^{[3]}$ A six-letter alphabet could indeed expand the codon table from 64 to 216 possibilities $\left(4^{3}\right.$ to $6^{3}$ ), enabling the formation of a large number of new amino acids, which can be translated into proteins with unknown functionalities and structures. ${ }^{[4]}$ An expanded genetic alphabet also serves for the creation of semi-synthetic organisms able to store increased information in their DNA. ${ }^{[4,5]}$ In addition, the increased chemical space and diversity provided by the presence of a third (or more ${ }^{[6]}$ additional base pair has already been hijacked to isolate modified aptamers with enhanced affinity and selectivity. ${ }^{[6 a, 7]}$

Despite these promising achievements, some UBPs are prone to dephosphorylation ${ }^{[8]}$ while cyclic $\pi$-conjugated analogs can be photoactivated by near-visible light producing reactive oxygen species that are highly toxic for DNA and cells. ${ }^{[9]}$ Hence, an alternative strategy has lately emerged with the use of metal coordination for the creation of artificial base pairs. Metalmediated base pairs are composed of nucleobases possessing coordination sites and a bridging metal ion. These systems are orthogonal to the natural Watson-Crick base pairs, possess a high thermal stability, present water-solubility, do not absorb UV light and cause only minimal distortions to canonical duplexes. ${ }^{[10]}$ Considering these assets, metal-mediated base pairs have been explored intensively ${ }^{[11]}$ for various applications such as DNA-based logic gates ${ }^{[12]}$, metal nanowires ${ }^{[13]}$ or charge transfer capability. ${ }^{[14]}$ Interestingly, the presence of artificial ligands is not strictly required for the formation of metal-mediated base pairs since the formation of $\mathrm{T}$ $\mathrm{Hg}^{\mathrm{II}}-\mathrm{T}, \mathrm{C}-\mathrm{Ag}^{\mathrm{I}}-\mathrm{C}$ or $\mathrm{C}-\mathrm{Ag}^{\mathrm{I}}-\mathrm{A}$ base pairs has also been reported. ${ }^{[15]}$ An important prerequisite for the use of metal-mediated base pairs in the expansion of the genetic alphabet is their acceptance by polymerases and surprisingly, only little is known about their enzymatic construction. One of the few examples is the orthogonal Salen- $\mathrm{Cu}^{\mathrm{II}}$ base pair (Fig. 1). ${ }^{[16]}$ It was reported to be fully compatible with enzymatic synthesis conditions since this UBP could be constructed by primer extension reactions and by-passed by polymerases. Full-length product formation was also observed in the presence of a mixture of all five nucleotides (natural A, C, G and T as well as the modified Salen nucleotide). The modified base pair could also be amplified by PCR in the presence of natural nucleotides. ${ }^{[17]}$ A similar result was obtained with the $\mathbf{P u r}^{\mathrm{DC}}-\mathrm{Cu}^{\mathrm{II}}-\mathbf{3 P y}$ base pair (Fig. 1), which could be formed by primer extension reactions with various polymerases. The artificial base pair could also be extended with canonical dNTPs. ${ }^{[18]}$ Lastly, 
hydroxypyridone nucleotides $(\mathbf{H})$ were successfully incorporated at the 3'-end of an oligonucleotide using the TdT polymerase. Addition of $\mathrm{Cu}^{\mathrm{II}}$ led to the formation of $\mathbf{H}-\mathrm{Cu}^{\mathrm{II}}-\mathbf{H}$ base pairs (Fig. 1). ${ }^{[19]}$ This system was also recently found to be formed by primer extension reactions and the artificial metal base pair could be by-passed using a two polymerases strategy which enabled the allosteric control of catalytic DNA molecules (DNAzymes). ${ }^{[20]}$

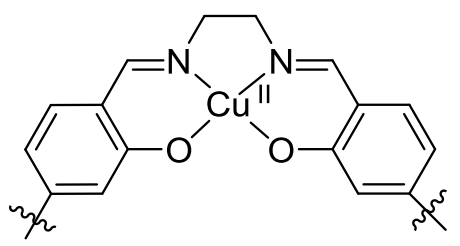

Salen-Cull

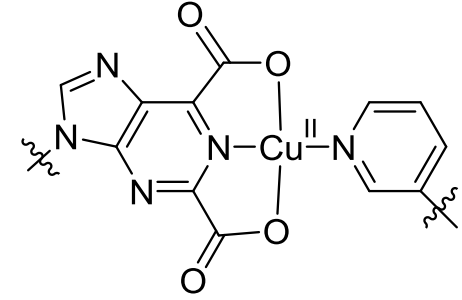

PurDC-Cull-3Py<smiles></smiles>

$\mathbf{H}-\mathrm{Cu}^{\prime \prime}-\mathbf{H}$

Fig. 1. Chemical structures of Salen-Cu ${ }^{\mathrm{II}}, \mathbf{P u r}{ }^{\mathrm{DC}}-\mathrm{Cu}^{\mathrm{II}}-\mathbf{3 P y}$ and $\mathbf{H}-\mathrm{Cu}^{\mathrm{II}}-\mathbf{H}$ base pairs.

In this context, a first attempt of enzymatic construction of an artificial base pair was previously performed in our laboratory using the modified triphosphate dImTP (Fig. 2). The imidazole moiety has indeed been intensively investigated since it was shown to form extremely stable Im-Ag ${ }^{\mathrm{I}}$-Im base pairs, with a thermal stability comparable to the A:T canonical pair. ${ }^{[21]}$ Importantly, an NMR structure of a DNA duplex containing a series of three $\mathbf{I m}-\mathrm{Ag}^{\mathrm{I}}-\mathbf{I m}$ base pairs revealed only minor distortions of the B-DNA duplex compared to canonical base pairs. ${ }^{[22]}$ Lastly, the small imidazole moiety can only serve as an acceptor for one hydrogen bond and consequently, is not expected to be misincorporated by polymerases in the absence of silver cations. ${ }^{[23]}$ However, the biochemical evaluation of $\mathbf{d I m T P}$ revealed that thermal stabilization and low structural perturbations were not the only important parameters for the enzymatic synthesis of UBP. ${ }^{[24]}$

A second generation of imidazole nucleotide was constructed, which possesses a carboxylic group on the imidazole ring (Fig. 2). Its presence allows the carboxyimidazole moiety to create a different coordination environment and the presence of a second hydrogen bond acceptor is expected to potentially reduce the interaction with natural nucleobases. Study of the $\mathbf{d} \mathbf{I m}^{\mathrm{C}}-\mathbf{M}^{\mathrm{n+}}-$ $\mathbf{d I m}^{\mathrm{C}}$ system led to a modest incorporation with $\mathrm{Mn}^{\mathrm{II}}, \mathrm{Fe}^{\mathrm{II}}, \mathrm{Co}^{\mathrm{II}}$ or $\mathrm{Cd}^{\mathrm{II}}$ cations. No multiple incorporations could be achieved and the UBP could not be by-passed by polymerases. Yet, a $\mathbf{d I m}^{\mathrm{C}}-\mathrm{Ag}^{\mathrm{I}}-\mathbf{d I m}$ base pair could be formed in a $[2+1]$ coordination environment. The incorporation of $\mathbf{d} \mathbf{I m}^{\mathbf{C}}$ seemed to be specific of the modification as no $n+1$ products was observed opposite to any canonical nucleotides. ${ }^{[25]}$ Interestingly, when $\mathbf{~} \mathbf{I m}^{\mathbf{C}}$ is incorporated by 
solid-phase synthesis into short oligonucleotides, formation of stable $\mathrm{Cu}^{\mathrm{II}}$ - and $\mathrm{Ag}^{\mathrm{I}}$-mediated base pairs could be observed suggesting that enzymatic synthesis and chemical synthesis are governed by different parameters. ${ }^{[26]}$

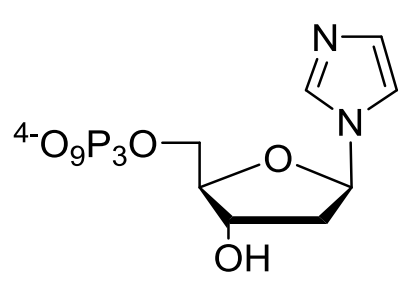

dImTP

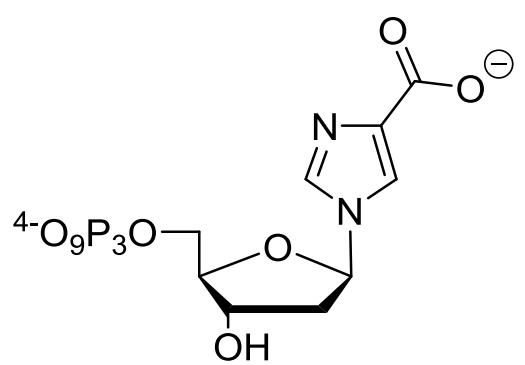

dlm ${ }^{\mathrm{c}} \mathrm{TP}$<smiles>[R2]c1cn(C2COC(CO[R5](=O)O)C(O)C2)c([R7])n1</smiles>

$$
\begin{array}{ll}
\mathrm{R}_{1}=\mathrm{CH}_{3}, \mathrm{R}_{2}=\mathrm{H} & 10 \\
\mathrm{R}_{1}=\mathrm{H}, & \mathrm{R}_{2}=\mathrm{CH}_{3} \\
\mathrm{R}_{1}=\mathrm{CH}_{3}, \mathrm{R}_{2}=\mathrm{CH}_{3} & 12
\end{array}
$$

Fig. 2. Chemical structures of $\operatorname{dIm} T P, \operatorname{dIm}^{\mathrm{C}} \mathbf{T P}$ and $\operatorname{dIm}^{\mathrm{nMe}} \mathbf{T P}(10,11$ and 12).

Therefore, a third generation of imidazole-modified triphosphates was considered for the construction of an artificial metal base pair, which possess a methyl group on positions 2 and 4 of the imidazole ring or a bis-methylated species (Fig. 2, 10, 11 and 12). A recent study of these nucleotide analogs showed that the presence of a methyl group led to a better shielding of the silver ion and consequently increased the thermal stability of the imidazole- $\mathrm{Ag}^{\mathrm{I}}$-imidazole base pair. ${ }^{[27]}$ Hence, we hypothesized that the presence of methyl group(s) could have a favourable impact on the enzymatic formation of a silver-mediated base pair. Herein, we demonstrate that the efficiency of the enzymatic formation of silver-mediated base pairs follows the trend $\mathbf{d I m}^{2 \mathrm{Me}}<\mathbf{d I m}{ }^{2,4 M e}<\mathbf{d I m}^{4 \mathrm{Me}}$ which is driven by steric factors rather than the $\mathrm{pK}_{\mathrm{a}}$ values of the imidazole moiety. The compatibility of ten underexplored metal cations with polymerases was confirmed under both PEX and PCR conditions, which led to the observation of the formation of a dIm ${ }^{2 M e} \mathbf{T P}-\mathrm{Cr}^{\mathrm{III}}-\mathbf{d I m}$ pair in good yields. 


\section{Results}

\section{Synthesis of the modified triphosphates and modified oligonucleotides}

The modified 2-methylimidazole (10, $\left.\mathbf{d I m}^{\mathbf{2 M e}}\right)$, 4-methylimidazole $\left(\mathbf{1 1}, \mathbf{d I m}^{\mathbf{4 M e}}\right)$ and 2,4dimethylimidazole (12, $\left.\mathbf{d I m}^{\mathbf{2}, \mathbf{4 M e}}\right)$ nucleoside triphosphates were synthesized by application of the Ludwig-Eckstein triphosphorylation conditions ${ }^{[28]}$ using the suitably $3^{\text {' }}-O$-Ac protected nucleoside analogs (Scheme 1).

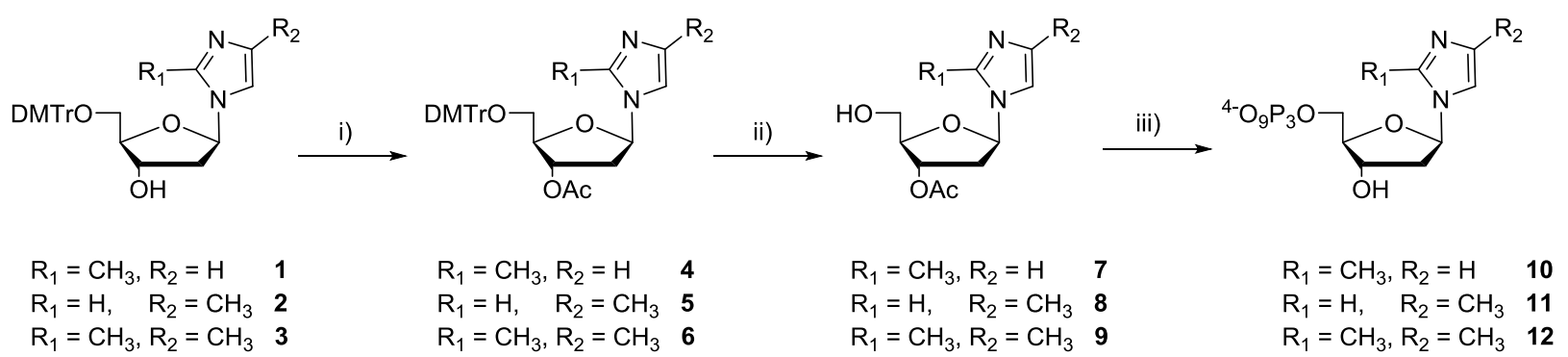

Scheme 1. Synthesis of methylimidazole triphosphates 10, 11 and 12. Reagents and conditions: (i) $\mathrm{Ac}_{2} \mathrm{O}, \mathrm{DMAP}, \mathrm{NEt}_{3}$, pyridine, $0^{\circ} \mathrm{C}, 1 \mathrm{~h}\left(4: 96 \%, 5: 62 \%\right.$, 6: 63\%); (ii) TCA $3 \%$ in $\mathrm{CH}_{2} \mathrm{Cl}_{2}, \mathrm{CH}_{2} \mathrm{Cl}_{2}, \mathrm{rt}$, $30 \min$ (7: 91\%, 8: 90\%, 9: 94\%); (iii) 1. 2-chloro-1,3,2-benzodioxaphosphorin-4-one, pyridine, dioxane, rt, 45 min; 2. $\left(\mathrm{nBu}_{3} \mathrm{NH}\right)_{2} \mathrm{H}_{2} \mathrm{P}_{2} \mathrm{O}_{7}, \mathrm{DMF}, \mathrm{nBu}_{3} \mathrm{~N}$, rt, $45 \mathrm{~min} ; 3 . \mathrm{I}_{2}$, pyridine, $\mathrm{H}_{2} \mathrm{O}, \mathrm{rt}, 30 \mathrm{~min} ; 4$. $\mathrm{NH}_{3}$ (aq.), rt, 2 h (10: 5\%, 11: 6\%, 12: 5\%, 4 steps).

In order to obtain oligonucleotides containing modified methylimidazole nucleotides, the corresponding phosphoramidites were synthesized either by following established protocols for $\mathbf{d I m}^{2 \mathbf{M e}}$ and $\mathbf{d I m}^{\mathbf{4 M e}}{ }^{[29]}$ or by standard phosphoramidite chemistry using nucleoside analog $\mathbf{3}$ (see the Supporting Information). ${ }^{[30]}$ Automated solid-phase synthesis was then performed to obtain the modified templates that are summarized in Table 1. Templates T1-T3 contain a methylimidazole-modified nucleotide located immediately downstream of the 3'-end of the FAM-labelled primer $\mathbf{P 1}$ and were designed to probe enzymatic synthesis of the artificial metal

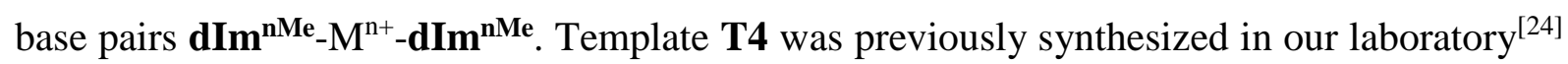
and was used to evaluate the possible formation of $\mathbf{d} \mathbf{I m}^{\mathbf{n M e}}-\mathbf{M}^{\mathrm{n+}}-\mathbf{d} \mathbf{I m}$ base pairs. 
Table 1. Sequences of the DNA primer and templates used for the primer extension reactions to assay the enzymatic synthesis of metal base pairs.

\begin{tabular}{|c|c|}
\hline $\mathbf{P 1}$ & 5'-FAM-TAC GAC TCA CTA TAG CCT C-3' \\
\hline $\mathbf{P 2}$ & 5'-GTG GTG CGA AAT TTC TGA C-3' \\
\hline $\mathbf{P 3}$ & 5'-CAC TCA CGT CAG TGA CAT GC-3' \\
\hline $\mathbf{P 4}$ & 5'-FAM-GTG GTG CGA AAT TTC TGA C-3' \\
\hline T1 & 5'-GGA GIm ${ }^{2 M e}$ G AGG CTA TAG TGA GTC GTA-3' \\
\hline $\mathbf{T 2}$ & 5'-GGA GIm ${ }^{4 \mathrm{Me}}$ G AGG CTA TAG TGA GTC GTA-3' \\
\hline T3 & 5'-GGA GIm ${ }^{2,4 M e}$ G AGG CTA TAG TGA GTC GTA-3' \\
\hline T4 & 5'-GGIm ImImG AGG CTA TAG TGA GTC GTA-3' \\
\hline T5-T8 & 5'-GGA GNG AGG CTA TAG TGA GTC GTA-3' \\
\hline \multirow[t]{3}{*}{ T9 } & 5'-CAC TCA CGT CAG TGA CAT GCA TGC CGA TGA CTA \\
\hline & GTC GTC ACT AGT GCA CGT AAC GTG CTA GTC AGA \\
\hline & AAT TTC GCA CCA C -3 , \\
\hline
\end{tabular}

${ }^{a} \mathrm{~N}=\mathrm{A}($ T5) $; \mathrm{N}=\mathrm{C}($ T6) $; \mathrm{N}=\mathrm{G}($ T7 $) ; \mathrm{N}=\mathrm{T}($ T8) .

Formation of $\mathrm{dIm}^{\mathrm{nMe}}-\mathrm{M}^{\mathrm{n+}}-\mathrm{dIm}{ }^{\mathrm{nMe}}$ and $\mathrm{dIm}^{\mathrm{nMe}}-\mathrm{M}^{\mathrm{n}+}-\mathrm{dIm}$ base pairs: initial polymerase screening.

The enzymatic formation of artificial base pairs was assessed in an initial screen with seven different polymerases known to accept modified nucleoside triphosphates as substrates ${ }^{[17-18]}$ (i.e. Taq, Bst, Therminator, Vent (exo-), Deep Vent, Dpo4 and $\mathrm{Kf}\left(\mathrm{exo}^{-}\right)$) and twelve different metal cations (see Supporting Information). All three modified nucleotides were first tested for their incorporation into DNA opposite their equivalent modified template in primer extension (PEX) reactions (i.e. $\mathbf{d I m}{ }^{2 M e} \mathbf{T P}$ was used with template $\mathbf{T 1}, \mathbf{d I m}^{\mathbf{4 M e}} \mathbf{T P}$ with template $\mathbf{T} 2$ and $\mathbf{d I m}^{2,4 M e} \mathbf{T P}$ with template T3). The envisioned homo base pairs are presented in Fig. 3.

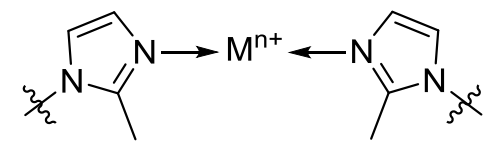

$\mathrm{Im}^{2 \mathrm{Me}}-\mathrm{M}^{\mathrm{n}+}-\mathrm{Im}^{2 \mathrm{Me}}$

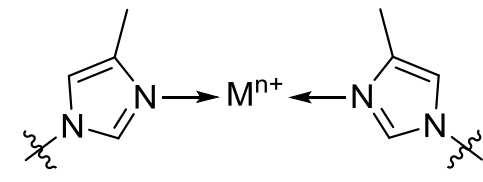

$\mathrm{Im}^{4 \mathrm{Me}}-\mathrm{M}^{\mathrm{n}+}-\mathrm{Im}^{4 \mathrm{Me}}$<smiles></smiles>

$1 m^{2,4 M e}-M^{n+}-1 m^{2,4 M e}$

Fig. 3. Chemical structures of $\mathbf{d I m}^{2 \mathrm{Me}}-\mathrm{M}^{\mathrm{n+}+}-\mathrm{dIm}^{2 \mathrm{Me}}, \mathbf{d I m}^{4 \mathrm{Me}}-\mathrm{M}^{\mathrm{n+}}-\mathbf{d I m}^{4 \mathrm{Me}}$ and $\mathbf{d I m}^{2,4 M e}-\mathrm{M}^{\mathrm{nt}}-\mathbf{d I m}^{2,4 M e}$. 
In all cases, only exonucleolytic degradation of primer $\mathbf{P 1}$ was observed with Taq, Bst, Therminator and Deep Vent polymerases (data not shown). dIm ${ }^{2 M e} \mathbf{T P}$ does not seem to be well tolerated as a substrate by the Vent (exo-) polymerase as only degradation products were detected (Fig. S1C). No incorporation of the modified nucleotide was observed with $\mathrm{Kf}\left(\mathrm{exo}^{-}\right)$ polymerase with any of the metal cations (Fig. S1B). For Dpo4 polymerase, partial incorporation was observed when $\mathrm{Cd}^{\mathrm{II}}, \mathrm{Co}^{\mathrm{II}}, \mathrm{Cu}^{\mathrm{II}}, \mathrm{Fe}^{\mathrm{III}}$ and $\mathrm{Ni}^{\mathrm{II}}$ metal cations were used but a similar yield of incorporation was observed in the control reactions carried out in the absence of metal ions (Fig. S1A). The initial screen with the nucleotide $\mathbf{d I m}^{\mathbf{4 M e}} \mathbf{T P}$ revealed partial formation of the expected $\mathrm{n}+1$ product in the presence of various metal ions with $\mathrm{Dpo} 4$ and $\mathrm{Kf}$ $\left(\right.$ exo $\left.^{-}\right)$polymerases but a similar ratio was detected in the control reaction (Fig. S2A and $\mathbf{S 2 B}$ ). Vent (exo ${ }^{-}$) does not accept $\mathbf{d} \mathbf{I m}^{\mathbf{4 M e}} \mathbf{T P}$ as a substrate since only degradation products could be observed (Fig. S2C). Analysis of the oligonucleotide containing a $\mathbf{d I m} \mathbf{I m}^{2,4 M e}$ nucleotide (template T3) also showed its partial incorporation with Dpo4 polymerase for all metal cations and in their absence (Fig. S3A). Vent (exo $)$ and $\mathrm{Kf}\left(\right.$ exo $\left.^{-}\right)$did not lead to any incorporation event (Fig. S3B and C). A summary of these findings can be found in Table 2. Clearly, the formation of the metal-mediated homo base pairs highlighted in Figure 3 is not supported by polymerases, potentially due to unfavourable steric clash between the methyl substituents. 
Table 2. Summary of the initial polymerase screening results with methylimidazole triphosphates. For $\mathbf{d I m}^{2 \mathrm{Me}}-\mathbf{M}^{\mathrm{n}+}-\mathbf{d} \mathbf{I m}^{2 \mathrm{Me}}$ : the incorporation of $\mathbf{d} \mathbf{I m}^{2 \mathrm{Me}} \mathbf{T P}$ (200 $\mu \mathrm{M}$ final concentration) opposite a single $\mathbf{d I m}^{2 \mathrm{Me}}$ in the presence of various metal cations was assessed using primer $\mathbf{P 1}$ and template T1. For $\mathbf{d I m}^{\mathbf{4 M e}}-\mathbf{M}^{\mathrm{n+}}-\mathbf{d} \mathbf{I m}^{\mathbf{4 M e}}: \mathbf{d I m}^{\mathbf{4 M e}} \mathbf{T P}(200 \mu \mathrm{M}$ final concentration $)$ and various metal cations were used with primer $\mathbf{P 1}$ and template $\mathbf{T} 2$. For $\mathbf{d} \mathbf{I m}^{2,4 M e}-\mathbf{M}^{\mathrm{n}+}-\mathbf{d} \mathbf{I m}^{2,4 M e}$ : the incorporation of $\mathbf{d I m}^{2,4 M e} \mathbf{T P}$ ( $200 \mu \mathrm{M}$ final concentration) opposite a single $\mathbf{d I m}^{\mathbf{2}, 4 \mathrm{Me}}$ in the presence of various metal cations was assessed using primer $\mathbf{P 1}$ and template $\mathbf{T 3}$.

\begin{tabular}{|c|c|c|c|}
\hline Polymerase & $\mathrm{dIm}^{2 \mathrm{Me}}-\mathrm{M}^{\mathrm{n}+}-\mathrm{dIm}^{2 \mathrm{Me}}$ & 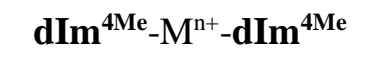 & $\mathrm{dIm}^{2,4 \mathrm{Me}}-\mathrm{M}^{\mathrm{n}+}-\mathrm{dIm}^{2,4 \mathrm{Me}}$ \\
\hline $\mathrm{Taq}$ & Degradation & Degradation & Degradation \\
\hline Bst & Degradation & Degradation & Degradation \\
\hline Therminator & Degradation & Degradation & Degradation \\
\hline Vent $\left(e^{2 x o^{-}}\right)$ & Degradation & Degradation & No incorporation \\
\hline Deep Vent & Degradation & Degradation & Degradation \\
\hline Dpo4 & $\begin{array}{l}\text { Partial incorporation } \\
\text { with } \mathrm{Cd}^{\mathrm{II}}, \mathrm{Co}^{\mathrm{II}}, \mathrm{Cu}^{\mathrm{II}} \text {, } \\
\mathrm{Fe}^{\mathrm{III}}, \mathrm{Ni}^{\mathrm{II}}\end{array}$ & $\begin{array}{c}\text { Partial incorporation } \\
\text { with all metal } \\
\text { cations }^{\mathrm{a}}\end{array}$ & $\begin{array}{c}\text { Partial incorporation } \\
\text { with all metal } \\
\text { cations }^{\mathrm{a}}\end{array}$ \\
\hline $\mathrm{Kf}\left(e \times o^{-}\right)$ & No incorporation & $\begin{array}{c}\text { Partial incorporation } \\
\text { with all metal } \\
\text { cations }^{\mathrm{a}}\end{array}$ & No incorporation \\
\hline
\end{tabular}

${ }^{\mathrm{a}} \mathrm{Ag}^{\mathrm{I}}, \mathrm{Cd}^{\mathrm{II}}, \mathrm{Co}^{\mathrm{II}}, \mathrm{Cu}^{\mathrm{II}}, \mathrm{Eu}^{\mathrm{III}}, \mathrm{Fe}^{\mathrm{II}}, \mathrm{Fe}^{\mathrm{III}}, \mathrm{Hg}^{\mathrm{II}}, \mathrm{Mn}^{\mathrm{II}}, \mathrm{Ni}^{\mathrm{II}}, \mathrm{Pb}^{\mathrm{II}}$, and $\mathrm{Zn}^{\mathrm{II}}$.

Based on the results stemming from these initial screens, we decided to test the enzymatic incorporation of all three modified nucleoside triphosphates with template $\mathbf{T 4}$, which contains three $\mathbf{d I m}$ nucleotides located immediately after the 3'-end of primer P1 and thus reduces the possibility of steric clashes. The envisioned hetero base pairs are presented in Fig 4.

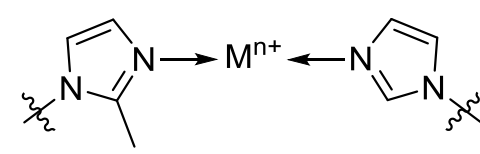

$$
\mathrm{Im}^{2 \mathrm{Me}}-\mathrm{M}^{\mathrm{n}+}-\mathrm{Im}
$$<smiles></smiles>

$\mathrm{Im}^{4 \mathrm{Me}}-\mathrm{M}^{\mathrm{n+}}-\mathrm{Im}$<smiles></smiles>

$\mathrm{Im}^{2,4 M e_{-}}-\mathrm{M}^{\mathrm{n+}}-\mathrm{Im}$

Fig. 4. Chemical structures of $\mathbf{d I m}^{2 \mathrm{Me}}-\mathrm{M}^{\mathrm{n+}}-\mathrm{dIm}, \mathrm{dIm}^{4 \mathrm{Me}}-\mathrm{M}^{\mathrm{n+}+}-\mathrm{dIm}$ and $\mathbf{d I m}^{2,4 \mathrm{Me}}-\mathrm{M}^{\mathrm{n+}}-\mathrm{dIm}$. 
For all modified triphosphates, only degradation products or unreacted primer were observed with Bst, Therminator, Deep Vent and Vent $\left(\mathrm{exo}^{-}\right)$polymerases regardless of the nature or the presence of the metal cation (data not shown). The analysis of the enzymatic formation of a $\mathbf{d I m}^{2,4 M e}$-containing metal-mediated base pair revealed formation of the $\mathrm{n}+1$ product in $\sim 50 \%$ yield in the presence of $\mathrm{Cd}^{\mathrm{II}}$ and $\mathrm{Mn}^{\mathrm{II}}$ with $\mathrm{Dpo} 4$ polymerase but the same incorporation occurred in the control reaction (Fig. S4A). Complete conversion to the $n+1$ product was observed when the Taq polymerase and $\mathrm{Mn}^{\mathrm{II}}$ were used (Fig. S4B). However, as manganese is known to relax the polymerase fidelity and the substrate specificity, this incorporation event is unlikely to correspond to the formation of a true metal base pair. ${ }^{[31]}$ Our screen revealed that the $\mathrm{Kf}\left(e x o^{-}\right)$polymerase enabled the formation of a $\mathbf{d I m} \mathbf{I m}^{\mathbf{2}, \mathbf{M e}}-\mathrm{Ag}^{\mathrm{I}}-\mathbf{d I m}$ base pair with $\sim 50 \%$ efficiency (Fig. S4C) with no incorporation in the control reaction carried out in the absence of metal ions. $\mathbf{d I m}{ }^{2 M e} \mathbf{T P}$ was not recognized as a substrate by the Taq and Dpo4 polymerases as only degradation products were detected (Fig. S5). Kf (exo $o^{-}$polymerase led to $\sim 40 \%$ of $n+1$ products with silver ions but $\sim 20 \%$ of incorporation was detected in the control reaction (Fig. S7A). The study of $\mathbf{d I m}^{\mathbf{4 M e}} \mathbf{T P}$ with Taq and $\mathrm{Kf}\left(\mathrm{exo}^{-}\right)$polymerases revealed the formation of $\sim 50 \%$ of $n+1$ products for all the metals tested and in the control reaction (Fig. S6A and Fig. S7B). Dpo4 polymerase led to formation of the $n+1$ product in low yields $(\sim 15 \%)$ in the presence of $\mathrm{Ag}^{\mathrm{I}}$ and no incorporation occurred in the control reaction (Fig. S6B).

\section{Optimization of the reaction conditions}

The initial polymerase screening revealed that $\mathbf{d} \mathbf{I m}^{2 \mathbf{2 M e}} \mathbf{T P}$ was a poor substrate for polymerases. However, since a partial incorporation was observed in the presence of $\mathrm{Ag}^{\mathrm{I}}$ and $\mathrm{Co}^{\mathrm{II}}$ we tried to optimize the reaction conditions in order to increase the incorporation efficiency detected with $\mathrm{Kf}\left(\mathrm{exo}^{-}\right)$and in the presence of these metal cations (Fig. 5). For $\mathrm{Ag}^{\mathrm{I}}$, all the experimental conditions that were tested including a reduction of the reaction time, the triphosphate concentration, and the silver ion concentration suppressed the formation of the $n+1$ product without reducing the background incorporation in the control reaction. Incorporation in the presence of $\mathrm{Co}^{\mathrm{II}}$ does not seem to be specific for the metal cation, since a similar ratio of $n+1$ products was detected in the control reaction under all the conditions tested. Therefore, the $\mathbf{d I m}^{2 \mathrm{Me}}$ nucleotide does not appear to be a suitable candidate for the enzymatic formation of artificial metal base pairs. 


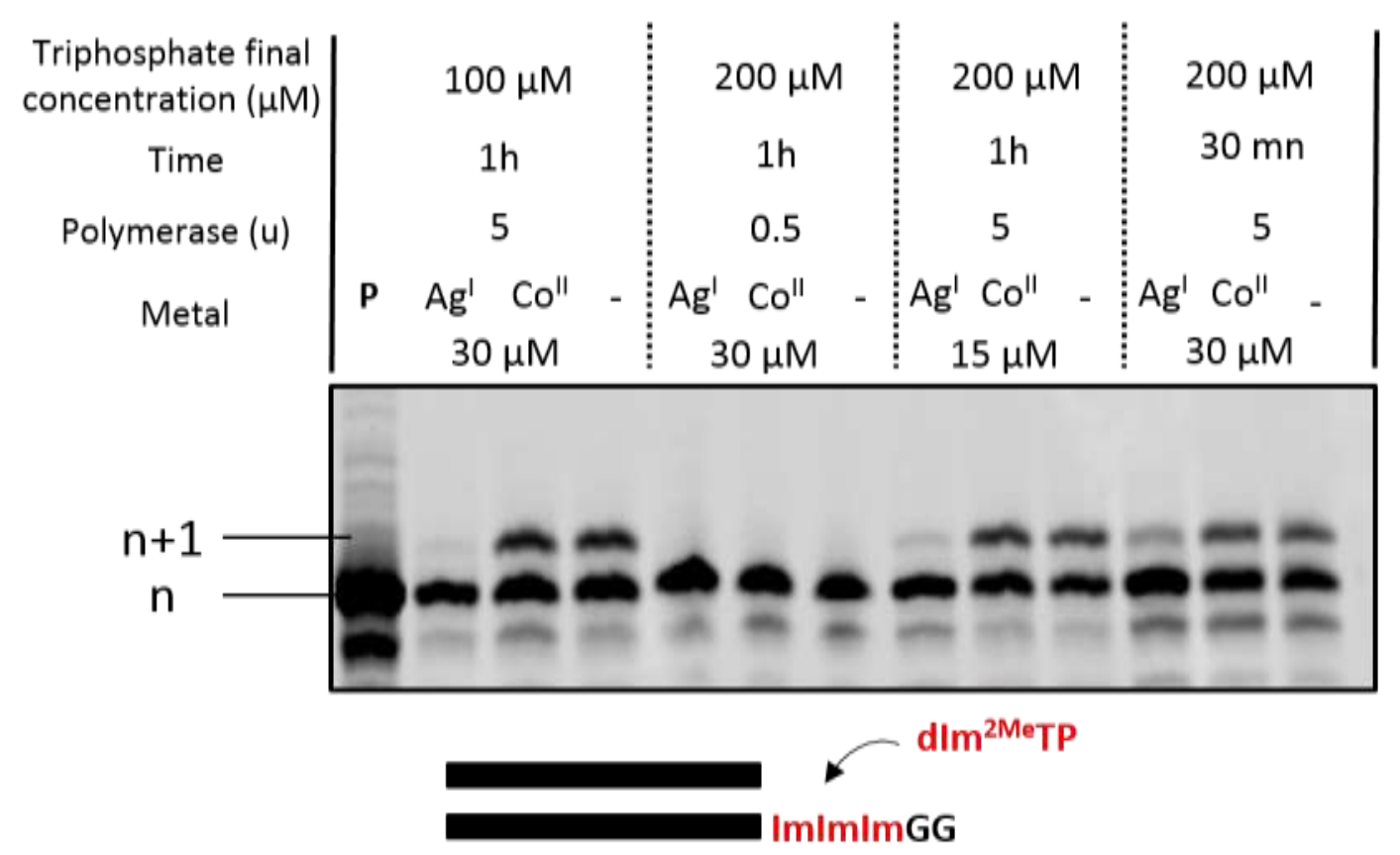

Fig. 5. Electrophoresis gel analysis of the incorporation of $\mathbf{d I m}^{\mathbf{2 M e}} \mathbf{T P}(100$ or $200 \mu \mathrm{M}$ final concentration) opposite a series of three Im nucleotides in the presence of $\mathrm{Co}^{\mathrm{II}}$ or $\mathrm{Ag}^{\mathrm{I}}$ using primer $\mathbf{P 1}$ and template $\mathbf{T} 4$ with $\mathrm{Kf}\left(\mathrm{exo}^{-}\right)$polymerase. Reaction mixtures were incubated at $37^{\circ} \mathrm{C}$ for 1 hour or 30 min. $\mathbf{P}$ indicates the unreacted primer. $\mathrm{Ag}^{\mathrm{I}}$ reaction conditions were performed with $\mathrm{AgNO}_{3}$ and $1 \mathrm{X}$ reaction buffer without any $\mathrm{Cl}^{-}$ions.

The initial screening with the $\mathbf{d} \mathbf{I m}^{\mathbf{2}, \mathbf{4 M e}}$ nucleotide revealed that this nucleotide was a more suitable candidate for the enzymatic formation of metal base pairs than $\mathbf{d I m}^{\mathbf{2 M e}}$ and thus we set out to optimize the reaction conditions with the $\mathrm{Kf}\left(\mathrm{exo}^{-}\right)$polymerase. Expectedly, a reduction of the polymerase concentration prevented any incorporation. On the other hand, increasing the reaction time to 2 or 4 hours allowed to improve the incorporation efficiency with $\operatorname{Ag}^{\mathrm{I}}(\sim 70 \%$ yield of $n+1$ product formation after 4 hours) but also to the appearance of $n+1$ products in the negative control ( $30 \%$ after 4 hours) (Fig. 6). Variation of the triphosphate or metal ion concentration both led to a diminution of the incorporation efficiency (data not shown). Thus, the $\mathbf{d I m}^{\mathbf{2}, \mathbf{4 M e}}$ nucleotide appears as a modest candidate for the enzymatic formation of an artificial base pair as the best conditions only led to $\sim 50 \%$ incorporation in the presence of $\mathrm{Ag}^{\mathrm{I}}$. 


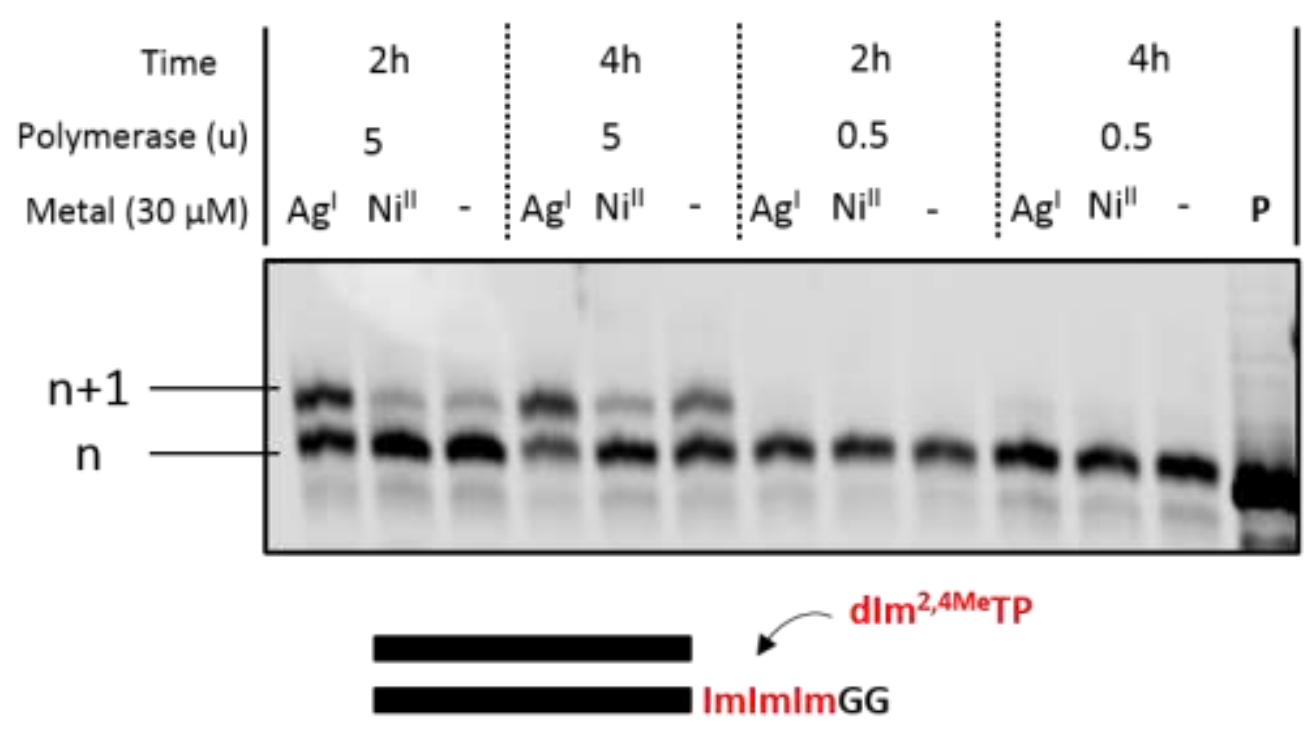

Fig. 6. PAGE (20\%) analysis of the formation of a $\mathbf{d I m}^{2,4 M e} \mathbf{T P}-\mathbf{M}^{\mathrm{n}+}-\mathbf{d I m}$ base pair using the primer P1/template T4 system with Kf (exo $)$ polymerase. $\mathbf{d I m}^{2,4 M e} \mathbf{T P}$ was used at $200 \mu \mathrm{M}$ final concentration and the reactions were incubated at $37^{\circ} \mathrm{C}$ for 2 or 4 hours. $\mathbf{P}$ indicates unreacted primer.

Also, for the most promising candidate identified by the initial screening ( $\left.\mathbf{d I m}{ }^{4 \mathbf{M e}} \mathbf{T P}\right)$, we tried to optimize the reaction conditions for the incorporation observed with $\mathrm{Ag}^{\mathrm{I}}$ and the Dpo4 polymerase. The incorporation efficiency reached $50 \%$ by increasing the metal ion concentration up to $100 \mu \mathrm{M}$. Yet, in these conditions, the time of the reaction cannot be varied since incorporation of the modified nucleotide could be detected in the control reaction when the reaction time was increased above 3 hours (Fig. 7, A). A yield of $\sim 70 \%$ of $n+1$ product formation was obtained when the triphosphate concentration was increased to $300 \mu \mathrm{M}$ in the presence of $200 \mu \mathrm{M}$ of $\operatorname{Ag}^{\mathrm{I}}$ (Fig. 7, B). Lastly, we doubled the polymerase concentration and performed the reactions with $200 \mu \mathrm{M}$ of triphosphate and different concentrations of $\mathrm{Ag}^{\mathrm{I}}$ (Fig. 7, C). Gratifyingly, around $80 \%$ conversion of the primer to the $n+1$ product was detected after 3 hours of reaction with clear metal ion dependence as only $\sim 10 \%$ incorporation was observed in the control reaction. Consequently, we increased the polymerase concentration up to eight units and the best results were obtained for 90 min of reaction, where $~ 90 \%$ of formation of the $\mathbf{d I m}^{\mathbf{4 M e}}-\mathrm{Ag}^{\mathrm{I}}-\mathbf{d I m}$ base pair was observed and only $\sim 10 \%$ incorporation in the negative control (Fig. 8). Such an incorporation efficiency compares favorably to that of other reported systems. Consequently, the compatibility of modified nucleotides with the enzymatic formation of silver-mediated UBPs follows the trend $\mathbf{d I m}^{\mathbf{2 M e}}<\mathbf{d} \mathbf{I m}^{\mathbf{2 , 4 M e}}<\mathbf{d I m}^{\mathbf{4 M e}}$. 


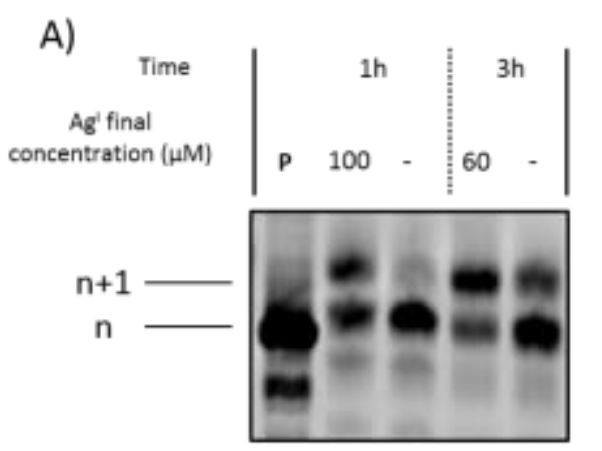

B)
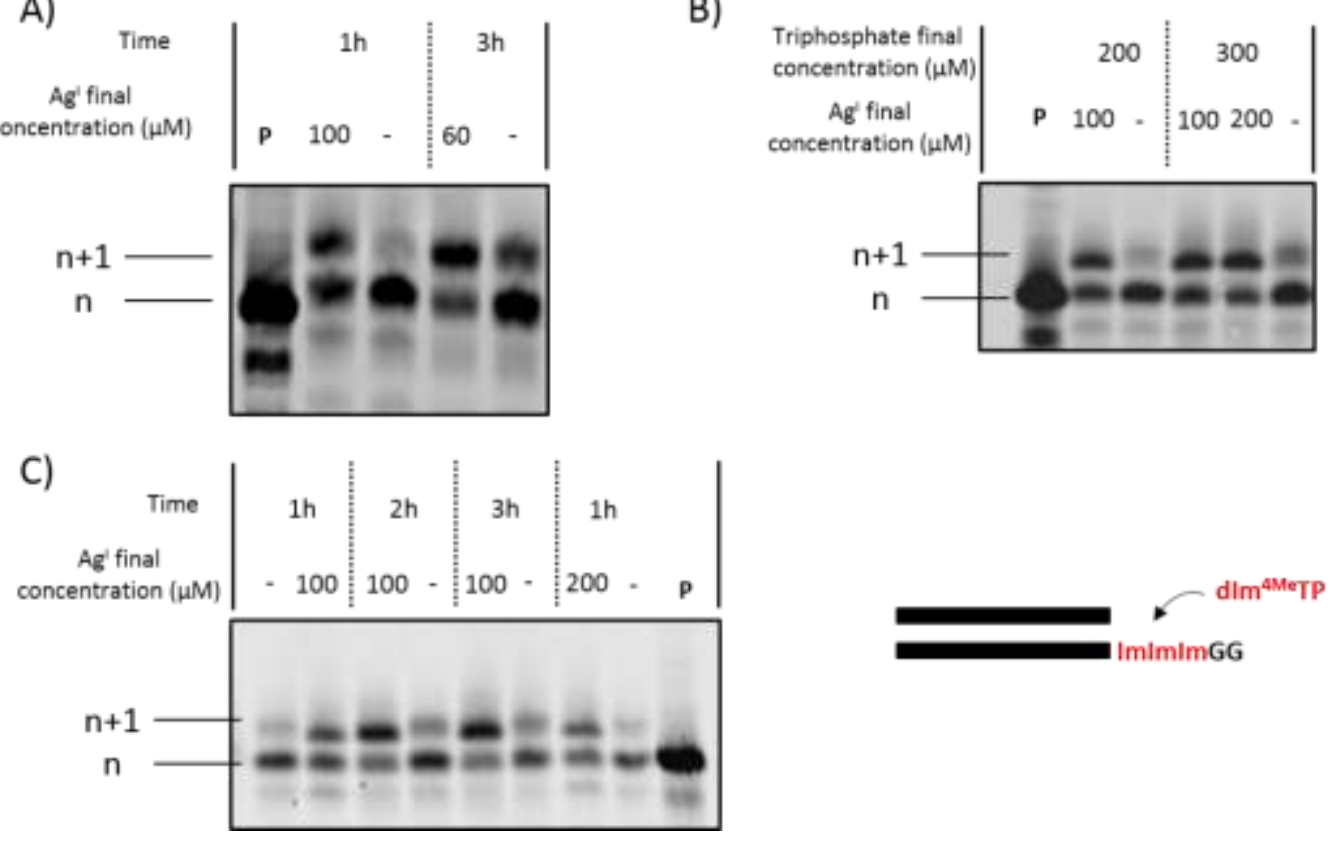

Fig. 7. Electrophoresis gel analysis of the incorporation of $\mathbf{d I m}^{4 \mathbf{M e}} \mathbf{T P}$ opposite a series of three $\mathbf{I m}$ nucleotide in the presence of $\mathrm{Ag}^{\mathrm{I}}$ using primer $\mathbf{P 1}$ and template $\mathbf{T} 4$ with Dpo4 polymerase. A) $\mathbf{d I m}^{4 \mathrm{Me}} \mathbf{T P}$ at $200 \mu \mathrm{M}$ final, Dpo4 (2 U), $55^{\circ} \mathrm{C}$; B $)$ Dpo4 (2 U), $55^{\circ} \mathrm{C}, 1 \mathrm{~h}$; C) dIm ${ }^{4 \mathrm{Me}} \mathbf{T P}$ at $200 \mu \mathrm{M}$ final, Dpo4 (4 U), $55^{\circ} \mathrm{C} . \mathbf{P}$ indicates the unreacted primer. $\mathrm{Ag}^{\mathrm{I}}$ reaction conditions were performed with $\mathrm{AgNO}_{3}$ and $1 \mathrm{X}$ reaction buffer without any $\mathrm{Cl}^{-}$ions.
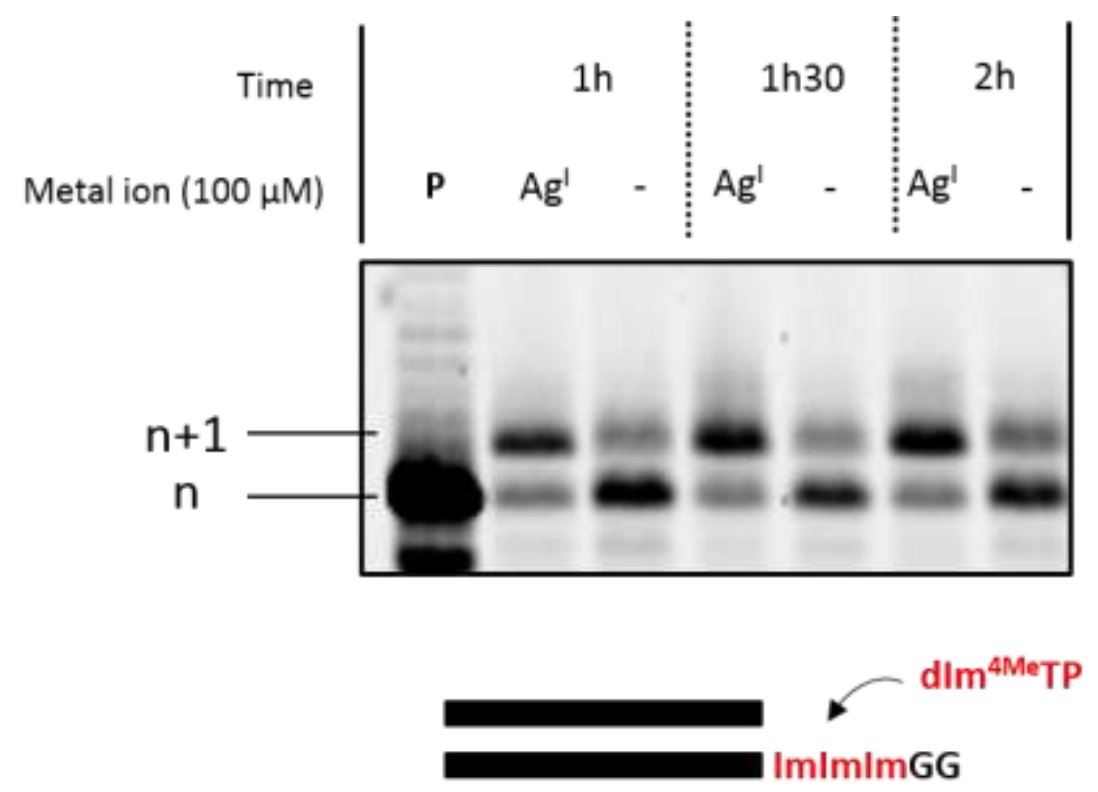

Fig. 8. PAGE (20\%) analysis of the formation of a $\mathbf{d I m}^{4 \mathbf{M e}} \mathbf{T P}-\mathbf{M}^{\mathrm{n}+}-\mathbf{d} \mathbf{I m}$ base pair using the primer P1/template T4 system with Dpo4 polymerase (8 U). $\mathbf{d I m}^{\mathbf{4 M e}} \mathbf{T P}$ was used at $200 \mu \mathrm{M}$ final concentration and the reactions were incubated at $55^{\circ} \mathrm{C}$ for different times. $\mathbf{P}$ indicates unreacted primer. 


\section{Specificity of the incorporation}

Having established conditions permitting the enzymatic formation of metal base pairs, we next investigated the specificity of the incorporation of $\mathbf{d I m}^{\mathbf{2 , 4 M e}} \mathbf{T P}$ and $\mathbf{d I m} \mathbf{I m e}^{\mathbf{4 M}} \mathbf{T P}$ opposite canonical nucleotides. PEX reactions were performed with primer P1 and natural templates T4T8, which contain each of the canonical nucleotides located immediately after the 3 '-end of P1. Both triphosphates were tested under the experimental conditions giving rise to the highest yields of $n+1$ product formation both in the absence and in the presence of $\mathrm{Ag}^{\mathrm{I}}$. For 2,4dimethyimidazole 12 with $\mathrm{Kf}\left(\mathrm{exo}^{-}\right)$polymerase, the presence of $\mathrm{Ag}^{\mathrm{I}}$ seems to slightly increase the incorporation opposite $\mathrm{dA}$ and $\mathrm{dC}$ nucleotides, as $\sim 15 \%$ yield of $\mathrm{n}+1$ product formation can be observed (Fig. 9). For templating dG and dT, a distribution of $n+1$ to $n+4$ products occurs in the absence of the metal ion. The addition of $\mathrm{Ag}^{\mathrm{I}}$ results in low misincorporation yields $(\leq 15 \%)$ of $\mathbf{d I m}^{\mathbf{2}, \mathbf{4 M e}}$. Overall, even though the enzymatic synthesis of the $\mathbf{d I m}^{\mathbf{2}, \mathbf{4 M e}}-\mathrm{Ag}^{\mathrm{I}}-\mathbf{d I m}$ base pair proceeds in moderate efficiency, it appears to be rather specific to the modified nucleotides and orthogonal to the canonical nucleotides.

The specificity of incorporation of the $\mathbf{d I m}^{\mathbf{4 M e}}$ nucleotide was tested with the Dpo4 polymerase. The analysis showed the formation of low yields $(\sim 10 \%)$ of $n+2$ products with template $\mathbf{T} 7$ and $\mathrm{n}+3$ products $(\sim 10 \%)$ with template $\mathbf{T 5}$ both in the presence and in the absence of $\mathrm{Ag}^{\mathrm{I}}$. The main misincorporation event was observed with a templating $\mathrm{dC}$ (template T6) in the presence of $\mathrm{Ag}^{\mathrm{I}}$ since about $50 \%$ conversion of the primer to the $\mathrm{n}+1$ product could be observed. The presence of the metal ion also led to $\sim 80 \%$ of $n+1$ products opposite to dT nucleotide and a distribution of $n+1$ to $n+5$ products is observed in its absence. These results indicate that the incorporation of $\mathbf{d I m}^{\mathbf{4 M e}} \mathbf{T P}$ is not entirely specific to templating modified nucleotides since partial misincorporation opposite canonical nucleotides occurs. 


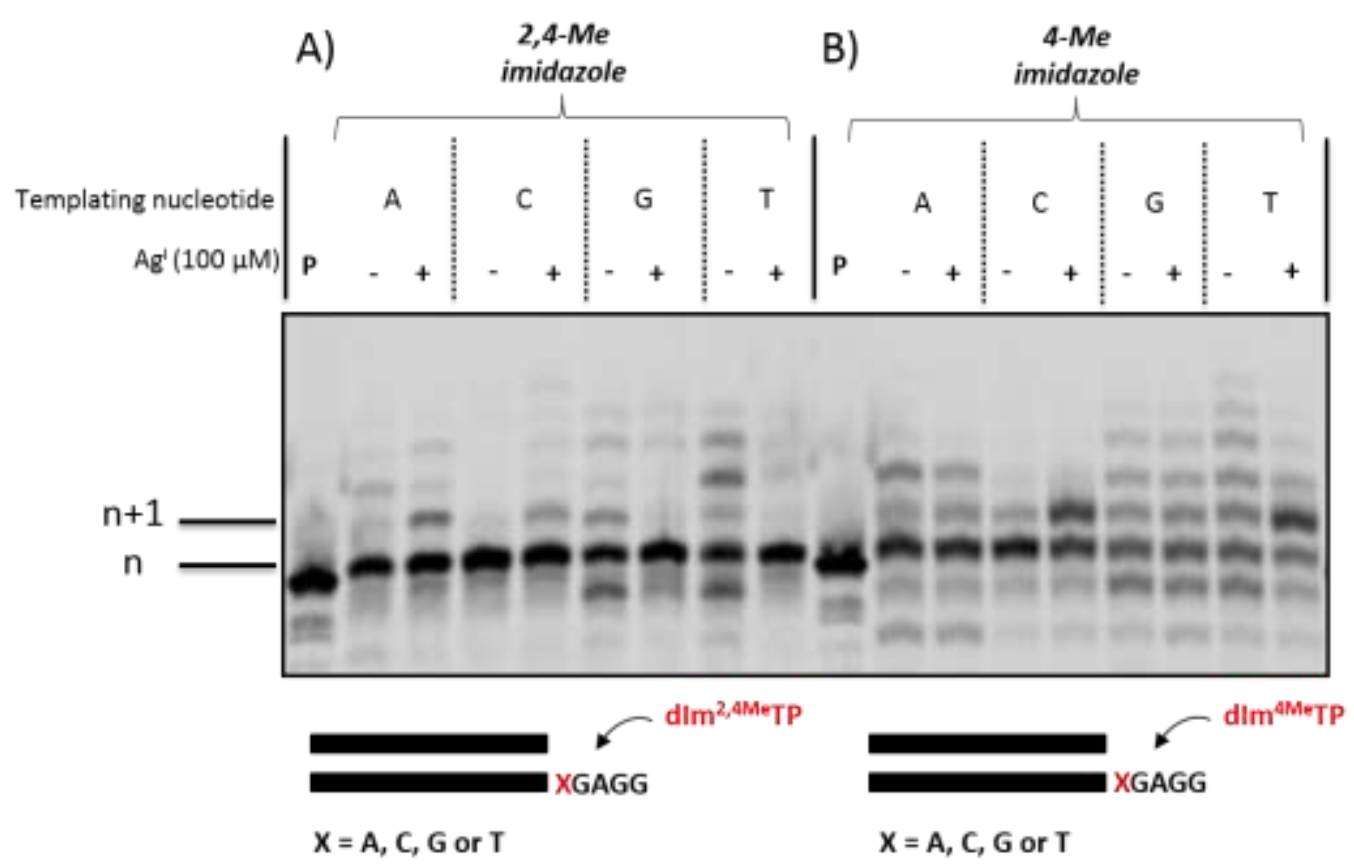

Fig. 9. Extension reactions with templates T5-T8. A) Triphosphate $\mathbf{d I m}^{\mathbf{2}, 4 \mathrm{Me}}$ (100 $\mu \mathrm{M}$ final) with $\mathrm{Kf}$ $\left(\mathrm{exo}^{-}\right)(10 \mathrm{U}), 30 \mathrm{~min}, 37^{\circ} \mathrm{C}$; B) Triphosphate ${\mathbf{~} \mathbf{I m}^{4 \mathrm{Me}}}\left(100 \mu \mathrm{M}\right.$ final) with Dpo4 (8 U), $30 \mathrm{~min}, 55^{\circ} \mathrm{C}$. $\mathbf{P}$ indicates unreacted primer.

\section{Compatibility of underexplored metal ions with enzymatic DNA synthesis.}

So far, most studies on the formation of metal base pairs have focused mainly on a limited set of $d$-block elements such as $\mathrm{Zn}^{\mathrm{II}}, \mathrm{Fe}^{\mathrm{I} / \mathrm{III}}, \mathrm{Cu}^{\mathrm{II}}, \mathrm{Ag}^{\mathrm{I}}, \mathrm{Ni}^{\mathrm{II}}, \mathrm{Hg}^{\mathrm{II}}$, and more recently $\mathrm{Pd}^{\mathrm{II}}$. ${ }^{[10 \mathrm{c}, \mathrm{d}, 11-12 \text {, }}$ ${ }^{16,18,20 a, 32]}$ In addition, the effect of metal cations on enzymatic synthesis of canonical DNA is largely underexplored and mainly restricted to biologically relevant metals ions. ${ }^{[33]}$ In addition, because the imidazole motif has been reported to be suitable ligands for various metal cations, ${ }^{[27,34]}$ we hypothesized that the presence of other metal ions such as $\mathrm{Cr}^{\mathrm{III}}, \mathrm{Ga}^{\mathrm{III}}$, or $\mathrm{Sc}^{\mathrm{III}}$ could be used to facilitate the enzymatic formation of $\mathbf{d} \mathbf{I m}^{\mathbf{n M e}}-\mathbf{M}^{\mathrm{n+}}-\mathbf{d} \mathbf{I m}^{\mathrm{nMe}}$ or $\mathbf{d I m} \mathbf{I m e}_{-} \mathbf{M}^{\mathrm{n+}}-$ dIm metal base pairs. However, prior to performing a screen with different metal species and the modified nucleotides, we evaluated the effect of ten metal salts and precursor complexes $\left(\mathrm{GaCl}_{3}, \mathrm{IrCl}_{3}, \mathrm{NaAuCl}_{4}, \mathrm{PdCl}_{2}, \mathrm{RuCl}_{3}, \mathrm{SbCl}_{3}, \mathrm{ScCl}_{3}, \mathrm{SrCl}_{2}, \mathrm{VCl}_{3}, \mathrm{KCr}\left(\mathrm{SO}_{4}\right)_{2}\right)$ on the enzymatic synthesis of canonical DNA under both PEX reaction and PCR conditions. To do so, we carried out PCR using natural dNTPs and the 79 nucleotide long template T9 along with a set of primers (P2 and P3) and asked whether five different polymerases could amplify the sequence in the presence of ten metal species with concentrations ranging from 0 to $100 \mu \mathrm{M}$ (Table 3 and Supporting Information). Similarly, we performed PEX reactions with the same 79-mer template T9 and primer P4 and canonical dNTPs. We also challenged five DNA polymerases 
to extend primer P4 in the presence of the different metal species (Table $\mathbf{4}$ and Supporting Information). Clearly, the presence of certain precursor complexes based on $\mathrm{Pd}^{\mathrm{II}}$ and $\mathrm{Ir}^{\mathrm{III}}$ had a negative impact on DNA amplification under PCR conditions while other species such as antimony oxychloride and $\mathrm{Sr}^{\mathrm{II}}$ had no influence on DNA synthesis under these conditions. On the other hand, the presence of the metal species was much more tolerated under PEX reaction conditions than with PCR since most polymerases were not inhibited and produced full-length products.

\begin{tabular}{|c|c|c|c|c|c|c|c|c|c|c|}
\hline Polymerase & $\mathrm{GaCl}_{3}$ & $\mathrm{IrCl}_{3}$ & $\overline{\mathrm{RuCl}_{3}}$ & $\overline{\mathrm{SbCl}_{3}}$ & $\mathrm{NaAuCl}_{4}$ & $\mathrm{PdCl}_{2}$ & $\mathrm{VCl}_{3}$ & $\mathrm{KCr}\left(\mathrm{SO}_{4}\right)_{2}$ & $\mathrm{SrCl}_{2}$ & $\mathrm{ScCl}_{3}$ \\
\hline Taq & 20 & & 20 & & 30 & 15 & & 30 & & 60 \\
\hline HemoKlen & & 30 & & & 30 & 60 & & & & \\
\hline Taq & & & & & & & & & & \\
\hline Vent $\left(e^{2 x o^{-}}\right)$ & 20 & 5 & 20 & & & 20 & 30 & & & 60 \\
\hline Q5 & & & 60 & & & 30 & & & & \\
\hline Phusion & & 20 & 30 & & & 30 & & & & 30 \\
\hline
\end{tabular}

Table 3. Summary of the systematic study of the influence of metal species on DNA synthesis by PCR using template T9 and primers P2 and P3. Red color represents inhibition of the synthesis with the threshold concentration (in $\mu \mathrm{M}$ ), while green color indicates no inhibition up to $100 \mu \mathrm{M}$.

\begin{tabular}{|c|c|c|c|c|c|c|c|c|c|c|}
\hline Polymerase & $\mathrm{GaCl}_{3}$ & $\mathrm{IrCl}_{3}$ & $\mathrm{RuCl}_{3}$ & $\mathrm{SbCl}_{3}$ & $\mathrm{NaAuCl}_{4}$ & $\mathrm{PdCl}_{2}$ & $\mathrm{VCl}_{3}$ & $\mathrm{KCr}\left(\mathrm{SO}_{4}\right)_{2}$ & $\mathrm{SrCl}_{2}$ & $\mathrm{ScCl}_{3}$ \\
\hline Taq & & 20 & & & & 60 & & 60 & & 60 \\
\hline Bst & & & & 60 & & & & & & \\
\hline Vent $\left(e x o^{-}\right)$ & & 30 & & & & 30 & & & & 5 \\
\hline Dpo4 & & & & & & & & & & 30 \\
\hline $\mathrm{Kf}\left(e x o^{-}\right)$ & & & & & & 60 & & & & \\
\hline
\end{tabular}

Table 4. Summary of the systematic study of the influence of metal species on DNA synthesis by PEX using template T9 and primer P4. Red color represents inhibition of the synthesis with the threshold concentration (in $\mu \mathrm{M}$ ), while green color indicates no inhibition up to $100 \mu \mathrm{M}$.

\section{Formation of $\mathrm{dIm}^{\mathrm{nMe}}-\mathrm{M}^{\mathrm{n}+}-\mathrm{dIm}{ }^{\mathrm{nMe}}$ and $\mathrm{dIm}^{\mathrm{nMe}}-\mathrm{M}^{\mathrm{n}+}-\mathrm{dIm}$ base pairs: initial polymerase screening with underexplored metal species.}

After ascertaining the compatibility of these metals with polymerases and enzymatic synthesis, we carried out a screen to evaluate whether the presence of the ten underexplored metal species could be exploited for the enzymatic construction of artificial metal base pairs. To do so, we 
used the modified templates $\mathbf{T 1}, \mathbf{T 2}$, and $\mathbf{T 3}$ along with their respective similar triphosphate $\mathbf{d I m}^{2 \mathrm{Me}} \mathbf{T P}, \mathbf{d I m}{ }^{4 \mathrm{Me}} \mathbf{T P}$ and $\mathbf{d I m}{ }^{2,4 M e} \mathbf{T P}$ (Fig. 3) using Bst, Dpo4 and $\mathrm{Kf}\left(e x o^{-}\right)$as polymerases. Surprisingly, no formation of the homo metal base pairs (yields of $n+1$ product formation < $10 \%$ ) could be detected for any of the modified triphosphates with the three polymerases tested and these ten underexplored metal species potentially due to steric clash of the methyl groups. We next thought to test these metal species (i.e. $\mathrm{GaCl}_{3}, \mathrm{IrCl}_{3}, \mathrm{NaAuCl}_{4}, \mathrm{PdCl}_{2}, \mathrm{RuCl}_{3}, \mathrm{SbCl}_{3}$, $\left.\mathrm{ScCl}_{3}, \mathrm{SrCl}_{2}, \mathrm{VCl}_{3}, \mathrm{KCr}\left(\mathrm{SO}_{4}\right)_{2}\right)$ with template $\mathbf{T} 4$ and $B s t$, Vent (exo $)$, Dpo4 and $\mathrm{Kf}\left(\right.$ exo $\left.^{-}\right)$ polymerases. PEX reactions conducted with $\mathbf{d I m}^{\mathbf{2}, 4 M e} \mathbf{T P}$ led to little $\mathrm{n}+1$ product formation with $B s t$ and Vent $\left(\mathrm{exo}^{-}\right)$and $\sim 50 \%$ conversion of the primer for every reaction (including the control reaction carried out in the absence of the respective metal species) for Dpo 4 and $\mathrm{Kf}$ (exo ${ }^{-}$) polymerases (data not shown). Reactions carried out with $\mathbf{d I m}^{\mathbf{2 M e}} \mathbf{T P}$ did not lead to any $\mathrm{n}+1$ product formation with Vent $\left(e x o^{-}\right)$and to non-specific incorporation with $\mathrm{Kf}\left(e x o^{-}\right)$(data not shown). Bst polymerase allowed the formation of a base pair with $\mathrm{Cr}^{\mathrm{III}}$ with $\sim 50 \%$ incorporation observed in the presence of $60 \mu \mathrm{M}$ metal cation concentration. Only a small fraction $(<10 \%)$ of $n+1$ products were detected with 20 or $60 \mu \mathrm{M}$ final concentration, attesting the metal dependency of the artificial base pair (Fig. S30). With Dpo4 polymerase, incorporation can be detected for most metal species, with a higher yield for $\mathrm{Au}^{\mathrm{III}}(\sim 30 \%)$ (Fig. S31).

$\mathbf{d I m}^{\mathbf{4 M e}} \mathbf{T P}$ was not accepted by Vent (exo-) and Dpo4 polymerases (data not shown) but led to the formation of a $\mathbf{d I m}^{\mathbf{4 M e}}-\mathrm{Cr}^{\mathrm{III}}-\mathbf{d I m}$ base pair without any detectable product formation in the control reaction carried out in the absence of $\mathrm{Cr}^{\mathrm{III}}$. This incorporation is clearly dependent on the concentration of $\mathrm{Cr}^{\mathrm{III}}$ since $\sim 15 \%$ of $\mathrm{n}+1$ products were detected in the presence of $20 \mu \mathrm{M}$ of $\mathrm{Cr}^{\mathrm{III}}$ while $\sim 60 \%$ yield was obtained when the concentration was increased to $60 \mu \mathrm{M}$ (Fig. S32). $\mathrm{Kf}\left(\mathrm{exo}^{-}\right)$polymerase led to the incorporation of most metal species at $20 \mu \mathrm{M}$ with a higher yield ( $80 \%)$ for the $\mathrm{Au}^{\mathrm{III}}$ cation (Fig. S33).

We next sought to improve the yield of formation of the $\mathbf{d I m}{ }^{2 \mathbf{M e}} \mathbf{T P}-\mathrm{Cr}^{\mathrm{III}}-\mathbf{d I m}$ base pair with the $B s t$ polymerase, and evaluated the influence of an increase of the time of the reaction and the $\mathrm{Cr}^{\mathrm{III}}$ concentration (Fig. 10). After 4 hours at $200 \mu \mathrm{M}$ concentration, around $60 \%$ of $\mathrm{n}+1$ products were detected. After 6 hours, incorporation starts to occur in the control reaction performed in the absence of $\mathrm{Cr}^{\mathrm{III}}$. The increase of the $\mathrm{Cr}^{\mathrm{III}}$ concentration to $300 \mu \mathrm{M}$ did not help to increase the incorporation yield. Lastly, we tried to combine $\mathrm{Cr}^{\mathrm{III}}$ with $\mathrm{Mn}^{\mathrm{II}}$, in order to favor the establishment of a $\mathbf{d I m}^{\text {2Me }} \mathbf{T P}-\mathrm{Cr}^{\mathrm{III}}-\mathbf{d I m}$ base pair. Surprisingly, $\mathrm{Mn}^{\mathrm{II}}$ seems to inhibit the formation of the latter as $\sim 30 \%$ of incorporation can be detected with both metals, whereas $\sim 50 \%$ was found when only $\mathrm{Cr}^{\mathrm{III}}$ was used. 


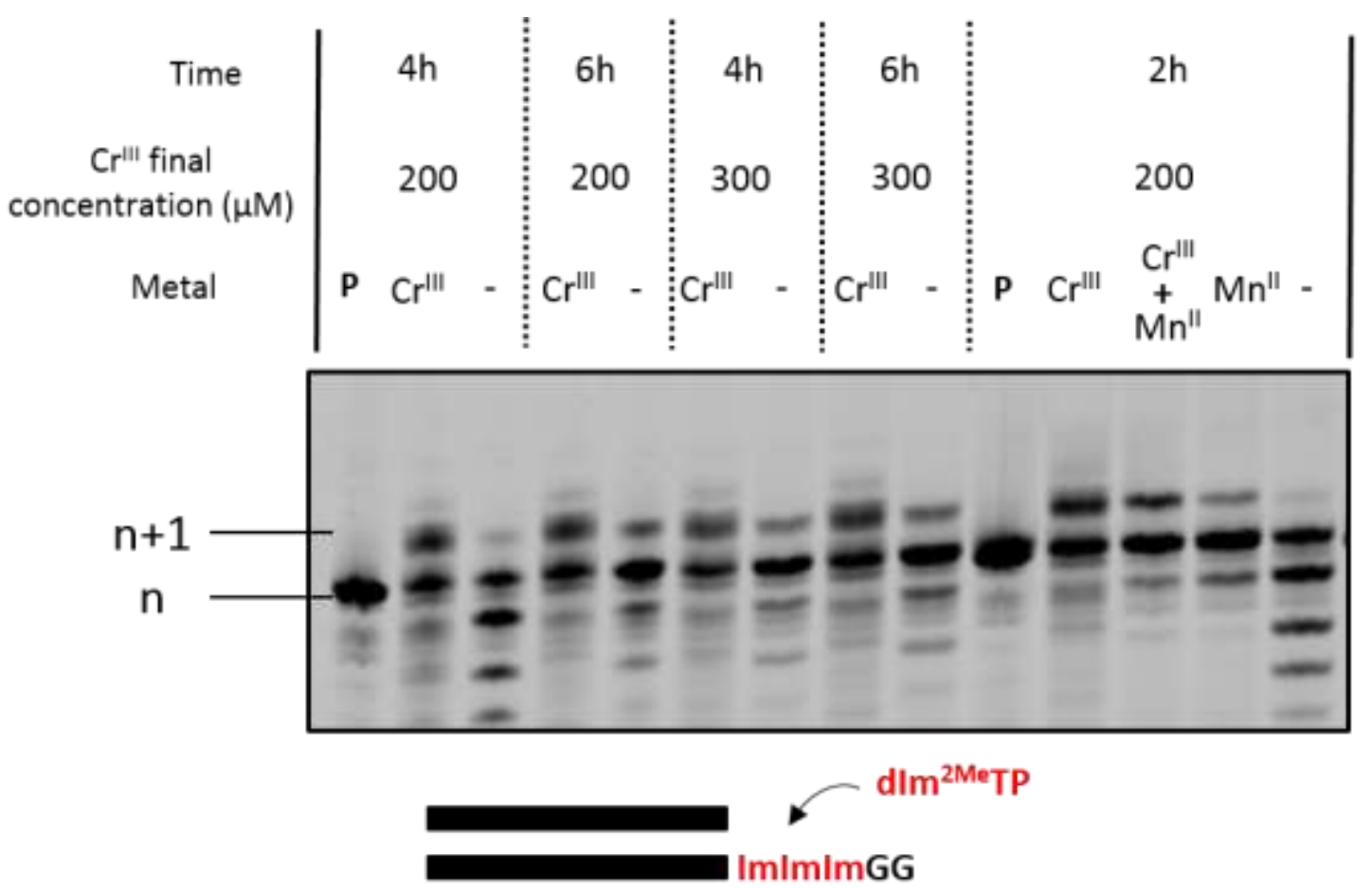

Fig. 10. PAGE (20\%) analysis of the formation of a $\mathbf{d I m}{ }^{2 \mathbf{M e}} \mathbf{T P}-\mathrm{Cr}^{\mathrm{III}}-\mathbf{d I m}$ base pair using the primer P1/template T4 system with $B s t$ polymerase ( $8 \mathrm{U}$ ). $\mathrm{Mn}^{\mathrm{II}}$ was used at $1 \mathrm{mM}$ final concentration and the reactions were incubated at $60{ }^{\circ} \mathrm{C}$ for 2,4 or 6 hours. $\mathbf{P}$ indicates unreacted primer.

The same methodology was applied to $\mathbf{d I m}^{\mathbf{4 M e}} \mathbf{T P}$ with the Bst and Dpo4 polymerases (Fig. S34). For Bst and $\mathrm{Cr}{ }^{\mathrm{III}}, \mathrm{n}+1$ product formation was detected in the control reaction after 4 hours ( $40 \%$ ). Yet, $\mathrm{Mn}^{\mathrm{II}}$ seems to help the incorporation of the modified triphosphate as $\sim 80 \%$ of $\mathrm{n}+1$ products were detected when both $\mathrm{Cr}^{\mathrm{III}}$ and $\mathrm{Mn}^{\mathrm{II}}$ were present, whereas $\sim 60 \%$ of incorporation occurred with $\mathrm{Cr}^{\mathrm{III}}$ alone and $\sim 70 \%$ for $\mathrm{Mn}^{\mathrm{II}}$ alone. Concerning Dpo4 polymerase, around $20 \%$ of the $\mathrm{n}+1$ product was observed with $\mathrm{Au}^{\mathrm{III}}$ after $2 \mathrm{~h}$ of reaction. Approximately $40 \%$ incorporation occurred when $\mathrm{Au}^{\mathrm{III}}$ was replaced by $\mathrm{Mn}^{\mathrm{II}}$ and the same amount was obtained in the presence of both metal species. 


\section{Discussion}

Despite displaying an exquisite fidelity of replication and a high propensity at distinguishing canonical nucleotides, DNA polymerases are highly tolerant to chemical alterations brought to the scaffold of nucleoside triphosphates. ${ }^{[35]}$ This is particularly true for base-modified nucleotide analogues where a variety of functional groups ranging from small residues ${ }^{[36]}$ to large fragments including polymerases ${ }^{[37]}$ or even antibodies ${ }^{[38]}$ could be introduced into nucleic acids via polymerases. In the general context of identifying novel UBPs, the nucleotide candidate needs to be fully orthogonal to canonical DNA and has to be inserted opposite a templating modified nucleotide with an error rate not lower than $10^{-3} .{ }^{[39]}$ These rather stringent criteria can be met if the UBP does not cause major perturbations of the major and minor groove interactions of the base pair under construction and the polymerase. Hence, various parameters need to be taken into consideration when designing UBPs including stacking capacity, ${ }^{[40]}$ thermal stability of the base pair, solvent interactions, ${ }^{[41]} \mathrm{p} K_{\mathrm{a}}$ values of the respective nucleotides, ${ }^{[42]}$ size-complementarity, ${ }^{[7 b, 43]}$ and minor groove interactions. ${ }^{[43-44]}$ Undoubtedly, these elements need to be included in the design of nucleotide analogues for the enzymatic construction of metal UBPs. Here, we investigated the effect of substitution of the imidazole motif on the formation of metal base pairs mediated by polymerases. The methylation of the imidazole nucleotides precludes the formation of such base pairs regardless of the position of the substituent since no $\mathbf{d I m}^{\mathbf{n M e}}-\mathbf{M}^{\mathrm{n}+}-\mathbf{d I m}^{\text {nMe }}$ homo base pairs were observed. Interestingly, these homo metal base pairs were found to stabilize short synthetic duplexes despite the presence of the methyl groups. ${ }^{[27]}$ On the other hand, a similar observation has already been made for the 4-carboxyimidazole nucleotide $\mathbf{d I m}^{\mathbf{C}} \mathbf{T P}$. On the other hand, the presence of a

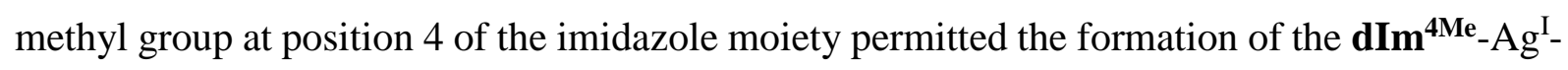
$\mathbf{d I m}$ hetero base pair mediated by the Dpo4 polymerase. In addition, formation of a $\mathbf{d I m}^{\mathbf{2 M e}}$ $\mathrm{Cr}^{\mathrm{III}}$-dIm hetero base pair with the Bst polymerase could be observed albeit in moderate yields. The formation of binary DNA.Cr ${ }^{I I I}$ complexes has recently been investigated, which appear to be mediated by the coordination of $\mathrm{N} 7$ of guanine nucleobases to a $\left[\mathrm{Cr}\left(\mathrm{H}_{2} \mathrm{O}\right)_{5}\right]^{3+}$ ion positioned in the major groove of dsDNA. ${ }^{[45]}$ A similar octahedral coordination environment is likely to exist during the formation of the $\mathbf{d I m}^{\mathbf{2 M e}}-\mathrm{Cr}^{\mathrm{III}}-\mathbf{d} \mathbf{I m}$ base pair, with seemingly vacant binding sites being occupied by aqua ligands, though a more thorough spectroscopic and structural investigation needs to be performed to shed light into the formation of this base pair. Collectively, these results suggest a beneficial influence of methyl groups located on the nucleobase compared to the parent $\mathbf{d I m} \mathbf{T P}$ with respect to metal base pair formation under 
enzymatic synthesis conditions. However, it is interesting to see that the propensity of the methylated imidazole nucleosides to engage in $\mathrm{Ag}^{\mathrm{I}}$-mediated base pairing does not follow the same trend as their $\mathrm{p} K_{\mathrm{a}}$ values do. These amount to 6.61 and 6.50 for $\mathbf{d I m}^{\mathbf{2 M e}}$ and $\mathbf{d I m} \mathbf{I m e}^{\mathbf{4 M e}}$, respectively, ${ }^{[27]}$ as well as $7.19 \pm 0.04$ for $\mathbf{d I m}^{2,4 M e}$ (Fig. S35). Hence, the least basic nucleoside is the most effective one at forming $\mathrm{Ag}^{\mathrm{I}}$-mediated base pairs during enzymatic oligonucleotide synthesis. This suggests that steric factors play a significantly more important role than electronic factors when it comes to the enzymatic incorporation of the respective dNTPs into oligonucleotides.

\section{Conclusion}

The appendage of methyl groups on the dIm nucleoside was previously shown to substantially increase the stability of duplexes containing $\mathbf{d I m}^{\mathbf{2 M e}}-\mathrm{Ag}^{\mathrm{I}}-\mathbf{d} \mathbf{I m}^{\mathbf{2 M e}}$ and $\mathbf{d I m ^ { 4 }} \mathbf{M e}_{-} \mathrm{Ag}^{\mathrm{I}}-\mathbf{d I m}{ }^{4 \mathbf{M e}}$ base pairs compared to duplexes with non-methylated nucleotides $\left(\Delta \Delta T_{\mathrm{m}}\right.$ of $2-3^{\circ} \mathrm{C}$ per base pair). Here, we have systematically investigated the effect of mono-methylation and bis-methylation of the imidazole nucleobase on the capacity at sustaining the formation of metal base pairs under enzymatic DNA synthesis conditions. While the methylation pattern precludes the formation of $\mathbf{d} \mathbf{I m}^{\mathrm{nMe}}-\mathrm{M}^{\mathrm{n}+}-\mathbf{d} \mathbf{I m}{ }^{\mathrm{nMe}}$ homo base pairs, we could identify conditions leading to a high yielding synthesis of a $\mathbf{d} \mathbf{I m}^{\mathbf{4 M e}}-\mathrm{Ag}^{\mathrm{I}}$-dIIm hetero base pair. We have also demonstrated the compatibility of metal cations that are usually not explored for the formation of metal base pairs with DNA synthesis under both PEX and PCR reaction conditions. This analysis was then extended to the methylated nucleotides and allowed us to construct a $\mathbf{d I m}^{\mathbf{2 M e}}-\mathrm{Cr}^{\mathrm{III}}-\mathbf{d I m}$ base pair. The effect of the methyl groups on the efficiency of metal base pair formation appears to be governed by steric factors rather than basicity of the imidazole moiety. Collectively this study shows that steric factors play an important role in the enzymatic construction of artificial metal base pairs and need to be included in the design of nucleotide analogues. 


\section{Experimental section}

\section{General methods and material}

All reactions were performed under argon in flame-dried glassware. Anhydrous solvents for reactions were obtained from Sigma Aldrich. Flash chromatography was performed using silica gel (230-400 mesh) from Sigma Aldrich. Thin layer chromatography was carried out on pre-coated glass-backed plates of silica gel (0.25 mm, UV254) from Macherey-Nagel. All chemicals and solvents used were purchased from Sigma-Aldrich and Alfa Aesar. NMR spectra were recorded on a Bruker Avance 400 spectrometer $\left(400.13 \mathrm{MHz}\right.$ for ${ }^{1} \mathrm{H}, 100.62 \mathrm{MHz}$ for ${ }^{13} \mathrm{C}$, and $161.62 \mathrm{MHz}$ for ${ }^{31} \mathrm{P}$ ) and all spectra were referenced to the signals of the corresponding solvent. Chemical shifts are given in ppm ( $\delta$ scale) and coupling constants $(J)$ in $\mathrm{Hz}$. Assignation of the NMR signals was performed by using a combination of ${ }^{1} \mathrm{H} /{ }^{1} \mathrm{H}-\mathrm{COSY},{ }^{13} \mathrm{C}$ DEPT-135, and ${ }^{13} \mathrm{C} /{ }^{1} \mathrm{H}-\mathrm{HMBC}$ experiments. High-resolution electrospray ionization (ESI) mass spectra (MS, m/z) were recorded on a Waters Q-Tof Micro MS in the positive-ion electrospray ionization (ESI+) mode. Solutions were prepared using 1:1 $\mathrm{MeCN} / \mathrm{H}_{2} \mathrm{O}$ containing $0.1 \%$ formic acid or $\mathrm{MeOH} /$ water containing $10 \mathrm{mM}$ ammonium acetate in the case of sensitive compounds. HPLC purification was performed using an Äkta ${ }^{\mathrm{TM}}$ pure system (GE Healthcare) equipped with Thermo Scientific ${ }^{\mathrm{TM}}$ DNAPac ${ }^{\mathrm{TM}}$ PA100 semi preparative ion exchange column $(13 \mu \mathrm{m}, 250 \times 9.0 \mathrm{~mm})$. Unmodified DNA oligonucleotides were purchased from Microsynth. DNA oligonucleotides containing modified nucleotides were synthesized on an H-8 DNA synthesizer from K\&A on a $1 \mu \mathrm{mol}$ scale. Natural DNA phosphoramidites (dT, dC4bz,

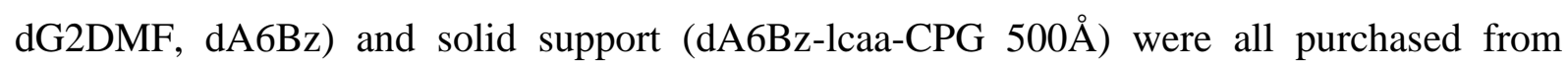
ChemGenes. The phosphoramidites were prepared by application of literature protocols. ${ }^{[27,29]}$ Natural DNA phosphoramidites as well as the modified phosphoramidite were prepared as 0.07 M solutions in MeCN and were coupled using $50 \mathrm{sec}$ and $490 \mathrm{sec}$ steps, respectively. 5(ethylthio)-1H-tetrazole ( $0.25 \mathrm{M}$ in $\mathrm{MeCN})$ was used as coupling agent. Capping, oxidation, and detritylation were performed using standard conditions. Cleavage from the solid support and deprotection of oligonucleotides was achieved by treatment with concentrated ammonia at $55^{\circ} \mathrm{C}$ for $16 \mathrm{~h}$. After centrifugation, the supernatants were collected and the resulting solutions were evaporated to dryness on a speed-vac. Crude oligonucleotides were purified by anion exchange HPLC (Dionex - DNAPac PA200). Buffer solutions of $25 \mathrm{mM}$ Tris- $\mathrm{HCl}$ in $\mathrm{H}_{2} \mathrm{O}, \mathrm{pH}$ 8.0 (buffer A) and $25 \mathrm{mM}$ Tris- $\mathrm{HCl}, 1.25 \mathrm{M} \mathrm{NaCl}$ in $\mathrm{H}_{2} \mathrm{O}$, pH 8.0 (buffer B) were used. The purified oligonucleotides were then desalted with SepPack C-18 cartridges. Oligonucleotide 
concentrations were quantitated by UV spectroscopy using a UV5Nano spectrophotometer (Mettler Toledo). The chemical integrity of oligonucleotides was assessed by UPLC-MS analysis: UPLC was performed on a BEH C18 column (130 $\AA, 1.7 \mu \mathrm{m}, 2.1 \mathrm{~mm}$ x $50 \mathrm{~mm})$ from Waters, installed on an ACQUITY UPLC H-Class System (SQ Detector 2). A buffer containing $20 \mathrm{mM}$ TEA and $400 \mathrm{mM}$ HFIP in $\mathrm{H}_{2} \mathrm{O}$ was used with a linear gradient from 18 to $31 \%$ methanol within $5 \mathrm{~min}$ and a flow rate of $0.3 \mathrm{~mL} / \mathrm{min}$. All the DNA polymerases (Therminator, Vent (exo-), Deep Vent, Bst, Taq, and Klenow fragment of DNA polymerase I exo- $\left(\mathrm{Kf}\left(e^{-} o^{-}\right)\right)$ were purchased from New England Biolabs as well as the natural dNTPs. Acrylamide/bisacrylamide (29:1, 40\%) was obtained from Fisher Scientific. Visualization of PAGE gels was performed by fluorescence imaging using a using a Storm 860 or a Typhoon Trio phosphorimager with the ImageQuant software (both from GE Healthcare). The following metal compounds were used: $\mathrm{AgNO}_{3}, \mathrm{CdCl}_{2}, \mathrm{CuSO}_{4}, \mathrm{CoCl}_{2}, \mathrm{EuCl}_{3}, \mathrm{FeSO}_{4}, \mathrm{FeCl}_{3}, \mathrm{HgCl}_{2}$, $\mathrm{MnCl}_{2}, \mathrm{NiSO}_{4}, \mathrm{~Pb}(\mathrm{OAc})_{2}, \mathrm{ZnSO}_{4}, \mathrm{GaCl}_{3}, \mathrm{IrCl}_{3}, \mathrm{NaAuCl}_{4}, \mathrm{PdCl}_{2}, \mathrm{RuCl}_{3}, \mathrm{SbCl}_{3}, \mathrm{ScCl}_{3}, \mathrm{SrCl}_{2}$, $\mathrm{VCl}_{3}, \mathrm{KCr}\left(\mathrm{SO}_{4}\right)_{2}$.

\section{Reaction buffers}

The following 10x buffers without any $\mathrm{Cl}^{-}$source were prepared for PEX reactions in presence of $\mathrm{Ag}^{\mathrm{I}}$. Buffer 1 is used for Vent $\left(e x o^{-}\right)$, buffer 2 for $\mathrm{Kf}\left(e x o^{-}\right)$, and buffer 3 for Taq and buffer 4 for Bst.

Buffer 1: $200 \mathrm{mM}$ Tris acetate, $100 \mathrm{mM}\left(\mathrm{NH}_{4}\right)_{2} \mathrm{SO}_{4}, 100 \mathrm{mM} \mathrm{KClO}_{4}, 20 \mathrm{mM} \mathrm{MgSO} 40.1 \%$ Triton ${ }^{\circledR} \mathrm{X}-100, \mathrm{pH} 8.8$ at $25^{\circ} \mathrm{C}$; buffer 2: $500 \mathrm{mM} \mathrm{NaClO}$, $100 \mathrm{mM}$ Tris acetate, $100 \mathrm{mM}$ $\mathrm{MgSO}_{4}, 100 \mu \mathrm{M}$ DTT, pH 7.9; buffer 3: $100 \mathrm{mM}$ Tris acetate, $500 \mathrm{mM} \mathrm{KClO}_{4}, 15 \mathrm{mM} \mathrm{MgSO}_{4}$, pH 8.3 at $25^{\circ} \mathrm{C}$; buffer 4: $200 \mathrm{mM}$ Tris acetate, $100 \mathrm{mM}\left(\mathrm{NH}_{4}\right)_{2} \mathrm{SO}_{4}, 500 \mathrm{mM} \mathrm{KClO}{ }_{4}, 20 \mathrm{mM}$ $\mathrm{MgSO}_{4}, 0.1 \%$ Tween ${ }^{\circledR} 20, \mathrm{pH} 8.8$ at $25^{\circ} \mathrm{C}$.

\section{Synthesis of triphosphates}

$$
\text { Synthesis of 5'-O-(4,4'-dimethoxytrityl)-3'-O-acetyl-1',2'-dideoxy-1'-(2- }
$$

methylimidazol-1-yl)-ribofuranose (4):

The starting material 1 (100 mg, $0.17 \mathrm{mmol})$ was dissolved in dry pyridine $(5 \mathrm{~mL})$ at room temperature under argon. To this solution 2-(dimethylamino)pyridine ( $2.1 \mathrm{mg}, 0.017 \mathrm{mmol}, 0.1$ eq) and acetic anhydride ( $24 \mu \mathrm{L}, 0.26 \mathrm{mmol}, 1.5 \mathrm{eq}$.) were added. The reaction mixture was stirred for $3 \mathrm{~h}$ then quenched with methanol, concentrated under reduced pressure and purified by flash chromatography (DCM/MeOH 98:2) to yield $90 \mathrm{mg}(96 \%)$ of 4 as an oil. 
${ }^{1} \mathrm{H}$ NMR (400.13 MHz, $\mathrm{CDCl}_{3}$ ): $\delta=2.09$ (s, 3H), 2.12 (s, 3H), 2.44-2.60 (m, 2H), 3.36-3.37 (m, 2H), $3.81(\mathrm{~s}, 6 \mathrm{H}), 4.17-4.19(\mathrm{~m}, 1 \mathrm{H}), 5.43-5.45(\mathrm{~m}, 1 \mathrm{H}), 5.95-5.98(\mathrm{~m}, 1 \mathrm{H}), 6.83(\mathrm{dd}, J=$ $8.80 \mathrm{~Hz}, 4 \mathrm{H}), 6.90(\mathrm{~d}, J=1.60 \mathrm{~Hz}, 1 \mathrm{H}), 6.98-6.99(\mathrm{~d}, J=1.60 \mathrm{~Hz}, 1 \mathrm{H}), 7.28-7.32(\mathrm{~m}, 7 \mathrm{H})$, 7.41-7.43 (m, 2H).

${ }^{13} \mathrm{C} \mathrm{NMR}\left(100.62 \mathrm{MHz}, \mathrm{CDCl}_{3}\right): \delta=12.8,21.0,38.7,55.2,63.7,75.1,83.8,86.9,113.2,115.6$, $126.7,126.9,127.9,130.1,135.6,144.5,144.8,156.6,170.2,174.9$.

ESI MS $\mathrm{C}_{32} \mathrm{H}_{35} \mathrm{~N}_{2} \mathrm{O}_{6}{ }^{+} \mathrm{m} / \mathrm{z}$ calcd: 543.2940, found: 543.2504.

Synthesis of 5'-O-(4,4'-dimethoxytrityl)-3'-O-acetyl-1',2'-dideoxy-1'-(4methylimidazol-1-yl)-ribofuranose (5):

Starting material 2 (100 mg, $0.199 \mathrm{mmol}, 1 \mathrm{eq})$ was dissolved in dry pyridine (3 mL) with 2(dimethylamino)pyridine (6 mg, $0.049 \mathrm{mmol}, 0.25 \mathrm{eq})$ and $\mathrm{Et}_{3} \mathrm{~N}(69 \mu \mathrm{L}, 0.726 \mathrm{mmol}, 2.5 \mathrm{eq})$. To this solution under argon, acetic anhydride ( $28 \mu \mathrm{L}, 0.299 \mathrm{mmol}, 1.5 \mathrm{eq})$ was added dropwise at $0^{\circ} \mathrm{C}$ and the reaction mixture was stirred for $1 \mathrm{~h}$. Saturated $\mathrm{NaHCO}_{3}(20 \mathrm{~mL})$ was then added to quench the reaction and the mixture was extracted with EtOAc $(3 \times 20 \mathrm{~mL})$, dried over $\mathrm{MgSO}_{4}$ and concentrated under reduced pressure. The product was then purified by flash chromatography (DCM/MeOH 96:4) to give $66 \mathrm{mg}$ of a white foam (62\%).

${ }^{1} \mathrm{H}$ NMR (400.13 MHz, MeOD): $\delta=2.06$ (s, 3H), 2.09 (s, 3H), 2.48-2.69 (m, 2H), 3.32-3.40 $(\mathrm{m}, 2 \mathrm{H}), 3.76(\mathrm{~s}, 6 \mathrm{H}), 4.14-4.17(\mathrm{~m}, 1 \mathrm{H}), 5.41-5.43(\mathrm{~m}, 1 \mathrm{H}), 6.02(\mathrm{t}, J=6.00 \mathrm{~Hz}, 1 \mathrm{H}), 6.83(\mathrm{dd}$, $J=8.00 \mathrm{~Hz}, 4 \mathrm{H}), 6.90(\mathrm{~s}, 1 \mathrm{H}), 7.27-7.30(\mathrm{~m}, 7 \mathrm{H}), 7.40-7.42(\mathrm{~m}, 2 \mathrm{H}), 7.70(\mathrm{~s}, 1 \mathrm{H})$.

${ }^{13} \mathrm{C}$ NMR (100.62 MHz, MeOD): $\delta=15.8,23.4,42.1,58.3,67.5,78.9,87.9,90.1,90.5,116.7$, $117.3,130.5,131.4,131.9,133.9,139.5,139.6,148.7,162.8,174.6$.

HRMS (ESI) for $\mathrm{C}_{32} \mathrm{H}_{35} \mathrm{~N}_{2} \mathrm{O}_{6}{ }^{+} \mathrm{m} / \mathrm{z}$ calcd: 543.2495; found: 543.2507.

Synthesis of 5'-O-(4,4'-dimethoxytrityl)-3'-O-acetyl-1',2'-dideoxy-1'-(2,4dimethylimidazol-1-yl)-ribofuranose (6):

3 (100 mg, $0.194 \mathrm{mmol}$, eq) was dissolved in dry pyridine with 2-(dimethylamino)pyridine (6 $\mathrm{mg}, 0.049 \mathrm{mmol}, 0.25 \mathrm{eq})$ and $\mathrm{Et}_{3} \mathrm{~N}(68 \mu \mathrm{L}, 0.485 \mathrm{mmol}, 2.5 \mathrm{eq})$. To this solution under argon, acetic anhydride $(27 \mu \mathrm{L}, 0.291 \mathrm{mmol}, 1.5 \mathrm{eq})$ was added dropwise at $0^{\circ} \mathrm{C}$ and the reaction mixture was stirred for $1 \mathrm{~h}$. Saturated $\mathrm{NaHCO}_{3}(20 \mathrm{~mL})$ was then added to quench the reaction and the mixture was extracted with EtOAc $(3 \times 20 \mathrm{~mL})$, dried over $\mathrm{MgSO}_{4}$ and concentrated under reduced pressure. The product was then purified by flash chromatography (DCM/MeOH 96:4) to give $68 \mathrm{mg}$ of a white foam $(63 \%)$.

${ }^{1} \mathrm{H}$ NMR (400.13 MHz, MeOD): $\delta=1.99$ (s, 3H), 2.06 (s, 3H), 2.37 (s, 3H), 2.44-2.66 (m, 2H), 
3.28-3.38 (m, 2H), $3.74(\mathrm{~s}, 6 \mathrm{H}), 4.11-4.14(\mathrm{~m}, 1 \mathrm{H}), 5.42-5.45(\mathrm{~m}, 1 \mathrm{H}), 5.99(\mathrm{t}, J=6.00 \mathrm{~Hz}$, $1 \mathrm{H}), 6.76(\mathrm{~s}, 1 \mathrm{H}), 6.81(\mathrm{dd}, J=8.80 \mathrm{~Hz}, 4 \mathrm{H}), 7.19-7.29(\mathrm{~m}, 7 \mathrm{H}), 7.39-7.41(\mathrm{~m}, 2 \mathrm{H})$.

${ }^{13} \mathrm{C}$ NMR (100.62 MHz, MeOD): $\delta=11.4,11.7,19.5,37.5,54.4,63.6,74.8,83.7,84.5,86.6$, 112.2, 112.8, 126.6, 127.4, 128.0, 130.0, 135.2, 135.6, 144.6, 144.8, 158.8, 170.7.

HRMS (ESI) for $\mathrm{C}_{33} \mathrm{H}_{37} \mathrm{~N}_{2} \mathrm{O}_{6}{ }^{+} \mathrm{m} / \mathrm{z}$ calcd: 557.2651; found: 557.2650.

Synthesis of 3'-O-acetyl-1',2'-dideoxy-1'-(2-methylimidazol-1-yl)-ribofuranose (7):

The starting material 4 (90 mg, $0.16 \mathrm{mmol})$ was dissolved in DCM $(5 \mathrm{~mL})$ at room temperature under argon. To this yellow solution TFA $(0.5 \mathrm{~mL}, 6.5 \mathrm{mmol}, 44$ eq. $)$ were added. After $30 \mathrm{~min}$ the reaction mixture was quenched with NAHCO3 sat. $(10 \mathrm{~mL})$ and extracted with DCM (3x $15 \mathrm{~mL}$ ). The organic layers were combined dried over MgSO4, concentrated and purified by flash chromatography (DCM/MeOH 2-10\%) to yield $35 \mathrm{mg}(91 \%)$ of a yellow solid.

${ }^{1} \mathrm{H}$ NMR (400.13 MHz, $\left.\mathrm{CDCl}_{3}\right): \delta=2.13$ (s, 3H), 2.45 (s, 3H), 2.41-2.59 (m, 2H), 3.82-3.83 (m, 2H), $4.01(\mathrm{bs}, 1 \mathrm{H}), 4.11-4.13(\mathrm{~m}, 1 \mathrm{H}), 5.38-5.39(\mathrm{~m}, 1 \mathrm{H}), 6.96(\mathrm{t}, J=6.00 \mathrm{~Hz}, 1 \mathrm{H}), 6.89$ (s, 1H), 7.14 (s, 1H).

${ }^{13} \mathrm{C}$ NMR $\left(100.62 \mathrm{MHz}, \mathrm{CDCl}_{3}\right): \delta=13.1,21.0,38.6,62.3,75.0,84.6,85.2,115.6,127.2$, $145.0,170.5$.

HRMS (ESI) for $\mathrm{C}_{11} \mathrm{H}_{17} \mathrm{~N}_{2} \mathrm{O}_{4}{ }^{+} \mathrm{m} / \mathrm{z}$ calcd: 241.1183, found: 241.1182.

Synthesis of 3'-O-acetyl-1',2'-dideoxy-1'-(4-methylimidazol-1-yl)-ribofuranose (8):

To a stirred solution of 5 (66 mg, $0.122 \mathrm{mmol}, 1 \mathrm{eq})$ in anhydrous DCM (1.5 mL) under argon was added TCA $(0.5 \mathrm{~mL})$. The reaction mixture was stirred for $30 \mathrm{mn}$ at room temperature. The solvent was removed in vacuo and the residue was purified by flash chromatography (DCM/MeOH 96:4) to give 23mg of a white solid (90\%).

${ }^{1} \mathrm{H}$ NMR (400.13 MHz, MeOD): $\delta=2.11$ (s, 3H), 2.37 (s, 3H), 2.66-2.71 (m, 2H), $3.66(\mathrm{~s}, 1 \mathrm{H})$, 3.80-3.84 (m, 2H), 4.25-4.27 (m, 1H), 5.38-5.41 (m, 1H), 6.25 (t, J = 6.80 Hz, 1H), 7.60 (s, $1 \mathrm{H}), 9.04(\mathrm{~s}, 1 \mathrm{H})$.

${ }^{13} \mathrm{C}$ NMR (100.62 MHz, MeOD): $\delta=8.5,19.4,39.2,61.3,74.6,86.9,88.7,115.9,130.8,133.1$, 170.7 .

HRMS (ESI) for $\mathrm{C}_{11} \mathrm{H}_{17} \mathrm{~N}_{2} \mathrm{O}_{4}{ }^{+} \mathrm{m} / \mathrm{z}$ calcd: 241.1188; found: 241.1192.

Synthesis of 3'-O-acetyl-1',2'-dideoxy-1'-(2,4-dimethylimidazol-1-yl)-ribofuranose (9): 
To a stirred solution of 6 (68 mg, $0.122 \mathrm{mmol}, 1 \mathrm{eq})$ in anhydrous DCM (1.5 mL) under argon was added TCA $(0.5 \mathrm{~mL})$. The reaction mixture was stirred for $30 \mathrm{~min}$ at room temperature. The solvent was removed in vacuo and the residue was purified by flash chromatography (DCM/MeOH 96:4) to give $29 \mathrm{mg}$ of a white solid (94\%).

${ }^{1} \mathrm{H}$ NMR (400.13 MHz, MeOD): $\delta=2.12$ (s, 3H), 2.31 (s, 3H), 2.63-2.66 (m, 2H), $2.68(\mathrm{~s}, 3 \mathrm{H})$, $3.67(\mathrm{~s}, 1 \mathrm{H}), 3.79-3.80(\mathrm{~m}, 2 \mathrm{H}), 4.21-4.23(\mathrm{~m}, 1 \mathrm{H}), 5.39-5.42(\mathrm{~m}, 1 \mathrm{H}), 6.22(\mathrm{t}, J=6.40 \mathrm{~Hz}$, 1H), 7.57 (s, 1H).

${ }^{13} \mathrm{C}$ NMR (100.62 MHz, MeOD): $\delta=8.4,9.4,19.4,38.1,61.3,74.6,86.2,86.5,114.9,128.5$, $143.7,170.7$.

HRMS (ESI) for $\mathrm{C}_{12} \mathrm{H}_{19} \mathrm{~N}_{2} \mathrm{O}_{4}{ }^{+} \mathrm{m} / \mathrm{z}$ calcd: 255.1345; found: 255.1349

Synthesis of 1',2'-dideoxy-1'-(2-methylimidazol-1-yl)-ribofuranose-5'-triphosphate (10):

Starting material 7 was coevaporated twice with pyridine and dried under reduced pressure overnight before the reaction. Tributylammonium pyrophosphate was dried under reduced pressure overnight before the reaction.

7 (45 mg, $0.187 \mathrm{mmol}, 1 \mathrm{eq})$ was dissolved in dry pyridine $(0.25 \mathrm{~mL})$ and dried dioxane $(0.5$ $\mathrm{mL}$ ) at room temperature under inert atmosphere. To this solution, 2-chloro-1,3,2benzodioxaphosphorin-4-one ( $54 \mathrm{mg}, 0.262 \mathrm{mmol}, 1.4 \mathrm{eq}$ ) was added and the reaction mixture was stirred for $45 \mathrm{~min}$. A solution of tributylammonium pyrophosphate (133 $\mathrm{mg}, 0.243 \mathrm{mmol}$, $1.3 \mathrm{eq})$, in dry DMF $(0.25 \mathrm{~mL})$ and tributylamine $(0.1 \mathrm{~mL})$ was added dropwise and the reaction mixture was stirred for another $45 \mathrm{~min}$. It was then oxidized by the addition of iodine $(76 \mathrm{mg}$, $0.299 \mathrm{mmol}, 1.6 \mathrm{eq})$ in pyridine $(1.3 \mathrm{~mL})$ and $\mathrm{H}_{2} \mathrm{O}(0.3 \mathrm{~mL})$. After $30 \mathrm{~min}$ of stirring, the excess of iodine was quenched with a sodium thiosulfate solution $(10 \% \mathrm{w} / \mathrm{v}$ in water) and the solution was concentrated under reduced pressure at $30^{\circ} \mathrm{C}$. The residue was treated with aqueous ammonia $(10 \mathrm{~mL})$ for $2 \mathrm{~h}$.

The suspension was then concentrated under reduced pressure at $30^{\circ} \mathrm{C}$. The residue was dissolved in $\mathrm{H}_{2} \mathrm{O}$ and precipitated by the addition of $\mathrm{NaClO}_{4} 2 \%$ in acetone. The crude product was purified by ion exchange HPLC (50\% B in 20 min; Buffer A) TEAB $10 \mathrm{mM} \mathrm{pH}=8$; Buffer B) TEAB $1 \mathrm{M} \mathrm{pH=8)}$ to yield $4 \mathrm{mg}(5 \%, 4$ steps $)$ of the pure triphosphate 10.

${ }^{1} \mathrm{H}$ NMR (400.13 MHz, D $2 \mathrm{O}$ pD 7.1): 0.91-1.68 (m, 2H), 2.63 (s, 3H), 3.00-3.04 (m, 2H), 4.14 (bs, 1H), $4.24(\mathrm{bs}, 1 \mathrm{H}), 6.25(\mathrm{t}, J=8.00 \mathrm{~Hz}, 1 \mathrm{H}), 7.29(\mathrm{~s}, 1 \mathrm{H}), 4.67(\mathrm{~s}, 1 \mathrm{H})$. 
${ }^{31} \mathrm{P}$ NMR (161.62 MHz, $\mathrm{D}_{2} \mathrm{O}$ pD 7.1): -21.8 (t, $\left.J=23.4 \mathrm{~Hz} 1 \mathrm{P}\right),-10.12$ (d, $\left.J=17.13 \mathrm{~Hz} 1 \mathrm{P}\right),-$ $8.82(\mathrm{~d}, J=24.4 \mathrm{~Hz} 1 \mathrm{P})$.

HRMS (ESI) for $\mathrm{C}_{9} \mathrm{H}_{16} \mathrm{P}_{3} \mathrm{~N}_{2} \mathrm{O}_{12}{ }^{-} \mathrm{m} / \mathrm{z}$ calcd: 436.9916 found: 436.9913.

Synthesis of 1',2'-dideoxy-1'-(4-methylimidazol-1-yl)-ribofuranose-5'-triphosphate (11):

Starting material $\mathbf{8}$ was coevaporated twice with pyridine and dried under reduced pressure overnight before the reaction. Tributylammonium pyrophosphate was dried under reduced pressure overnight before the reaction.

8 (23 mg, $0.096 \mathrm{mmol}, 1 \mathrm{eq})$ was dissolved in dry pyridine $(0.15 \mathrm{~mL})$ and dried dioxane $(0.3$ $\mathrm{mL}$ ) at room temperature under inert atmosphere. To this solution, 2-chloro-1,3,2benzodioxaphosphorin-4-one ( $28 \mathrm{mg}, 0.134 \mathrm{mmol}, 1.4 \mathrm{eq}$ ) was added and the reaction mixture was stirred for $45 \mathrm{~min}$. A solution of tributylammonium pyrophosphate $(68 \mathrm{mg}, 0.125 \mathrm{mmol}$, $1.3 \mathrm{eq})$, in dry DMF $(0.15 \mathrm{~mL})$ and tributylamine $(0.1 \mathrm{~mL})$ was added dropwise and the reaction mixture was stirred for another $45 \mathrm{~min}$. It was then oxidized by the addition of iodine $(39 \mathrm{mg}$, $0.153 \mathrm{mmol}, 1.6 \mathrm{eq})$ in pyridine $(0.8 \mathrm{~mL})$ and $\mathrm{H}_{2} \mathrm{O}(0.2 \mathrm{~mL})$. After $30 \mathrm{~min}$ of stirring, the excess of iodine was quenched with a sodium thiosulfate solution $(10 \% \mathrm{w} / \mathrm{v}$ in water) and the solution was concentrated under reduced pressure at $30^{\circ} \mathrm{C}$. The residue was treated with aqueous ammonia $(10 \mathrm{~mL})$ for $2 \mathrm{~h}$.

The suspension was then concentrated under reduced pressure at $30^{\circ} \mathrm{C}$. The residue was dissolved in $\mathrm{H}_{2} \mathrm{O}$ and precipitated by the addition of $\mathrm{NaClO}_{4} 2 \%$ in acetone. The crude product was purified by ion exchange HPLC (50\% B in $20 \mathrm{~min}$; Buffer A) TEAB 10mM pH=8; Buffer B) TEAB $1 \mathrm{M} \mathrm{pH=8)}$ to yield $2.5 \mathrm{mg}(6 \%)$ of the pure triphosphate $\mathbf{1 1}$.

${ }^{1} \mathrm{H}$ NMR (400.13 MHz, D $2 \mathrm{O}$ pD 7.1): 0.87-0.97 (m, 2H), 2.62 (s, 3H), 3.00-3.04 (m, 2H), $4.14(\mathrm{bs}, 1 \mathrm{H}), 4.23$ (bs, 1H), 6.25 (t, $J=6.40 \mathrm{~Hz}, 1 \mathrm{H}), 7.28$ (s, 1H), 7.63 (s, 1H).

${ }^{31} \mathrm{P}$ NMR (161.62 MHz, $\mathrm{D}_{2} \mathrm{O}$ pD 7.1): -21.46 (t, $\left.J=23.2 \mathrm{~Hz}, 1 \mathrm{P}\right),-10.20$ (d, $\left.J=19.2 \mathrm{~Hz}, 1 \mathrm{P}\right)$, $-8.87(\mathrm{~d}, J=13.4 \mathrm{~Hz}, 1 \mathrm{P})$.

HRMS (ESI) for $\mathrm{C}_{9} \mathrm{H}_{16} \mathrm{P}_{3} \mathrm{~N}_{2} \mathrm{O}_{12}{ }^{-} \mathrm{m} / \mathrm{z}$ calcd: 436.9916; found: 436.9915.

Synthesis of 1',2'-dideoxy-1'-(2,4-dimethylimidazol-1-yl)-ribofuranose-5'-triphosphate (12): 
Starting material 9 was coevaporated twice with pyridine and dried under reduced pressure overnight before the reaction. Tributylammonium pyrophosphate was dried under reduced pressure overnight before the reaction.

9 (29 mg, $0.114 \mathrm{mmol}, 1 \mathrm{eq})$ was dissolved in dry pyridine $(0.15 \mathrm{~mL})$ and dried dioxane $(0.3$ $\mathrm{mL}$ ) at room temperature under inert atmosphere. To this solution, 2-chloro-1,3,2benzodioxaphosphorin-4-one (33 $\mathrm{mg}, 0.159 \mathrm{mmol}, 1 \mathrm{eq}$ ) was added and the reaction mixture was stirred for $45 \mathrm{~min}$. A solution of tributylammonium pyrophosphate $(81 \mathrm{mg}, 0.148 \mathrm{mmol}$, $1.3 \mathrm{eq})$, in dry DMF $(0.15 \mathrm{~mL})$ and tributylamine $(0.1 \mathrm{~mL})$ was added dropwise and the reaction mixture was stirred for another $45 \mathrm{~min}$. It was then oxidized by the addition of iodine ( $46 \mathrm{mg}$, $0.182 \mathrm{mmol}, 1.6 \mathrm{eq})$ in pyridine $(0.8 \mathrm{~mL})$ and $\mathrm{H}_{2} \mathrm{O}(0.2 \mathrm{~mL})$. After $30 \mathrm{~min}$ of stirring, the excess of iodine was quenched with a sodium thiosulfate solution $(10 \% \mathrm{w} / \mathrm{v}$ in water) and the solution was concentrated under reduced pressure at $30^{\circ} \mathrm{C}$. The residue was treated with aqueous ammonia $(10 \mathrm{~mL})$ for $2 \mathrm{~h}$.

The suspension was then concentrated under reduced pressure at $30^{\circ} \mathrm{C}$. The residue was dissolved in $\mathrm{H}_{2} \mathrm{O}$ and precipitated by the addition of $\mathrm{NaClO}_{4} 2 \%$ in acetone. The crude product was purified by ion exchange HPLC (50\% B in 20 min; Buffer A) TEAB $10 \mathrm{mM} \mathrm{pH}=8$; Buffer B) TEAB $1 \mathrm{M} \mathrm{pH}=8)$ to yield $2.6 \mathrm{mg}(5 \%)$ of the pure triphosphate $\mathbf{1 2}$. ${ }^{1} \mathrm{H}$ NMR (400.13 MHz, D $2 \mathrm{O}$ pD 7.1): 0.91-1.68 (m, 2H), 2.23 (s, 3H), 2.58 (s, 3H), 3.02-3.04 (m, 2H), 4.13 (bs, 1H), 4.22 (bs, 1H), 6.19 (t, $J=6.00 \mathrm{~Hz}, 1 \mathrm{H}), 7.33$ (s, 1H).

${ }^{31} \mathrm{P}$ NMR (161.62 MHz, $\mathrm{D}_{2} \mathrm{O}$ pD 7.1): -21.3 (t, $\left.J=20.8 \mathrm{~Hz}, 1 \mathrm{P}\right),-10.95$ (d, $\left.J=19.7 \mathrm{~Hz}, 1 \mathrm{P}\right),-$ $5.25(\mathrm{~d}, J=20.5 \mathrm{~Hz}, 1 \mathrm{P})$.

HRMS (ESI) for $\mathrm{C}_{10} \mathrm{H}_{18} \mathrm{P}_{3} \mathrm{~N}_{2} \mathrm{O}_{12}{ }^{-} \mathrm{m} / \mathrm{z}$ calcd: 451.0073; found: 451.0070 .

\section{Primer extension experiments}

The 5'-FAM-labelled primer P1 (10 pmol) was annealed to the appropriate template (15 pmol) in water by heating to $95^{\circ} \mathrm{C}$ and then gradually cooling to room temperature (over 30 min). The appropriate polymerase buffer, DNA polymerase and metal cation solutions were then added to the annealed oligonucleotides mixture on ice. Finally, natural dNTPs and/or modified triphosphate were added for a total reaction volume of $10 \mu \mathrm{L}$. Following incubation at the optimal temperature for the enzyme, the reactions were quenched by adding stop solution (10 $\mu \mathrm{L}$; formamide (70\%), ethylenediaminetetraacetic acid (EDTA; $50 \mathrm{mM}$ ), bromophenol $(0.1 \%)$, xylene cyanol $(0.1 \%))$. The reaction mixtures were subjected to gel electrophoresis in denaturing polyacrylamide gel (20\%) containing trisborate-EDTA (TBE) $1 \times$ buffer $(\mathrm{pH} 8)$ and 
urea (7 M). Visualization was performed by fluorescence imaging a using a Storm 860 or a Typhoon Trio phosphorimager.

\section{Acknowledgements}

M.F. gratefully acknowledges a fellowship from the doctoral school MTCI University of Paris Descartes. The authors gratefully acknowledge financial support from Institut Pasteur. The start-up company DNA Script is acknowledged for help in the UPLC-MS analysis of the oligonucleotides. J.M. thanks the Deutsche Forschungsgemeinschaft for funding (SFB 858). S.N. gratefully acknowledges funding by the Westfälische Wilhelms-Universität Münster (PhD fellowship).

\section{Additional information}

Competing Interests: The authors declare no competing interests.

\section{References}

[1] a) Z. Yang, A. M. Sismour, P. Sheng, N. L. Puskar and S. A. Benner, Nucleic Acids Res 2007, 35, 4238-4249; b) Z. Yang, F. Chen, J. B. Alvarado and S. A. Benner, J. Am. Chem. Soc. 2011, 133, 15105-15112.

[2] a) E. T. Kool, Annu. Rev. Biophys. Biomol. Struct. 2001, 30, 1-22; b) M. Kimoto, R. Kawai, T. Mitsui, S. Yokoyama and I. Hirao, Nucleic Acids Res 2008, 37, e14-e14.

[3] D. L. McMinn, A. K. Ogawa, Y. Q. Wu, J. Q. Liu, P. G. Schultz and F. E. Romesberg, J. Am. Chem. Soc. 1999, 121, 11585-11586.

[4] a) D. A. Malyshev and F. E. Romesberg, Angew. Chem. Int. Ed. 2015, 54, 11930-11944; b) A. W. Feldmann and F. E. Romesberg, Acc. Chem. Res. 2018, 51, 394-403; c) K. H. Lee, K. Hamashima, M. Kimoto and I. Hirao, Curr. Opin. Biotechol. 2018, 51, 8-15; d) A. X. Z. Zhou, K. Sheng, A. W. Feldman and F. E. Romesberg, J. Am. Chem. Soc. 2019, 141, 20166-20170; e) A. W. Feldman, V. T. Dien, R. J. Karadeema, E. C. Fischer, Y. B. You, B. A. Anderson, R. Krishnamurthy, J. S. Chen, L. J. Li and F. E. Romesberg, J. Am. Chem. Soc. 2019, 141, 1064410653; f) E. C. Fischer, K. Hashimoto, Y. Zhang, A. W. Feldman, V. T. Dien, R. J. Karadeema, R. Adhikary, M. P. Ledbetter, R. Krishnamurthy and F. E. Romesberg, Nat. Chem. Biol. 2020, $16,570-576$.

[5] a) Y. K. Zhang, B. M. Lamb, A. W. Feldman, A. X. Zhou, T. Lavergne, L. J. Li and F. E. Romesberg, Proc. Natl. Acad. Sci. U.S.A. 2017, 114, 1317-1322; b) Y. Zhang, J. L. Ptacin, E. C. Fischer, H. R. Aerni, C. E. Caffaro, K. San Jose, A. W. Feldman, C. R. Turner and F. E. Romesberg, Nature 2017, 551, 644-647.

[6] a) L. Q. Zhang, Z. Y. Yang, K. Sefah, K. M. Bradley, S. Hoshika, M. J. Kim, H. J. Kim, G. Z. Zhu, E. Jimenez, S. Cansiz, I. T. Teng, C. Champanhac, C. McLendon, C. Liu, W. Zhang, D. L. Gerloff, Z. Huang, W. H. Tan and S. A. Benner, J. Am. Chem. Soc. 2015, 137, 6734-6737;

b) S. Hoshika, N. A. Leal, M.-J. Kim, M.-S. Kim, N. B. Karalkar, H.-J. Kim, A. M. Bates, N. 
E. Watkins, H. A. SantaLucia, A. J. Meyer, S. DasGupta, J. A. Piccirilli, A. D. Ellington, J. SantaLucia, M. M. Georgiadis and S. A. Benner, Science 2019, 363, 884-887.

[7] a) M. M. Georgiadis, I. Singh, W. F. Kellett, S. Hoshika, S. A. Benner and N. G. J. Richards, J. Am. Chem. Soc. 2015, 137, 6947-6955; b) R. Yamashige, M. Kimoto, Y. Takezawa, A. Sato, T. Mitsui, S. Yokoyama and I. Hirao, Nucleic Acids Res 2011, 40, 2793-2806; c) I. Okamoto, Y. Miyatake, M. Kimoto and I. Hirao, ACS Synth. Biol. 2016, 5, 1220-1230; d) M. Kimoto, R. Yamashige, K. Matsunaga, S. Yokoyama and I. Hirao, Nat. Biotech. 2013, 31, 453-457; e) K. Matsunaga, M. Kimoto and I. Hirao, J. Am. Chem. Soc. 2017, 139, 324-334.

[8] D. A. Malyshev, K. Dhami, T. Lavergne, T. J. Chen, N. Dai, J. M. Foster, I. R. Correa and F. E. Romesberg, Nature 2014, 509, 385-388.

[9] a) Q. Wang, X. Y. Xie, J. Han and G. L. Cui, J. Phys. Chem. B. 2017, 121, 10467-10478; b) M. Pollum, B. Ashwood, S. Jockusch, M. Lam and C. E. Crespo-Hernandez, J. Am. Chem. Soc. 2016, 138, 11457-11460.

[10] a) X. R. Guo, P. Leonard, S. A. Ingale and F. Seela, Chem. Eur. J. 2017, 23, 17740-17754; b) B. Jash, P. Scharf, N. Sandmann, C. Fonseca Guerra, D. A. Megger and J. Müller, Chem. Sci. 2017, 8, 1337-1343; c) J. Müller, Coord. Chem. Rev. 2019, 393, 37-47; d) S. Naskar, R. Guha and J. Müller, Angew. Chem. Int. Ed. 2020, 59, 1397-1406.

[11] P. Scharf and J. Müller, ChemPlusChem 2013, 78, 20-34.

[12] a) T. Carell, Nature 2011, 469, 45-46; b) K. S. Park, C. Jung and H. G. Park, Angew. Chem. Int. Ed. 2010, 49, 9757-9760; c) R. Freeman, T. Finder and I. Willner, Angew. Chem. Int. Ed. 2009, 48, 7818-7821.

[13] a) A. Ono, H. Kanazawa, H. Ito, M. Goto, K. Nakamura, H. Saneyoshi and J. Kondo, Angew. Chem. Int. Ed. 2019, 58, 16835-16838; b) J. Kondo, Y. Tada, T. Dairaku, Y. Hattori, H. Saneyoshi, A. Ono and Y. Tanaka, Nat. Chem. 2017, 9, 956-960; c) S. Vecchioni, M. C. Capece, E. Toomey, L. Nguyen, A. Ray, A. Greenberg, K. Fujishima, J. Urbina, I. G. PaulinoLima, V. Pinheiro, J. Shih, G. Wessel, S. J. Wind and L. Rothschild, Sci. Rep. 2019, 9, 6942.

[14] a) S. Liu, G. H. Clever, Y. Takezawa, M. Kaneko, K. Tanaka, X. Guo and M. Shionoya, Angew. Chem. Int. Ed. 2011, 50, 8886-8890; b) T. Ehrenschwender, W. Schmucker, C. Wellner, T. Augenstein, P. Carl, J. Harmer, F. Breher and H.-A. Wagenknecht, Chem. Eur. J. 2013, 19, 12547-12552; c) S. Hensel, K. Eckey, P. Scharf, N. Megger, U. Karst and J. Müller, Chem. Eur. J. 2017, 23, 10244-10248.

[15] a) A. Ono, H. Torigoe, Y. Tanaka and I. Okamoto, Chem. Soc. Rev. 2011, 40, 5855-5866; b) T. Funai, Y. Miyazaki, M. Aotani, E. Yamaguchi, O. Nakagawa, S.-i. Wada, H. Torigoe, A. Ono and H. Urata, Angew. Chem. Int. Ed. 2012, 51, 6464-6466; c) Y. Miyake, H. Togashi, M. Tashiro, H. Yamaguchi, S. Oda, M. Kudo, Y. Tanaka, Y. Kondo, R. Sawa, T. Fujimoto, T. Machinami and A. Ono, J. Am. Chem. Soc. 2006, 128, 2172-2173; d) A. Ono, S. Cao, H. Togashi, M. Tashiro, T. Fujimoto, T. Machinami, S. Oda, Y. Miyake, I. Okamoto and Y. Tanaka, Chem. Commun. 2008, 4825-4827.

[16] G. H. Clever, K. Polborn and T. Carell, Angew. Chem. Int. Ed. 2005, 44, 7204-7208.

[17] C. Kaul, M. Müller, M. Wagner, S. Schneider and T. Carell, Nat. Chem. 2011, 3, 794-800.

[18] E. K. Kim and C. Switzer, ChemBioChem 2013, 14, 2403-2407.

[19] a) T. Kobayashi, Y. Takezawa, A. Sakamoto and M. Shionoya, Chem. Commun. 2016, 52, 3762-3765; b) Y. Takezawa, T. Kobayashi and M. Shionoya, Int. J. Mol. Sci. 2016, 17, 10.

[20] a) Y. Takezawa, T. Nakama and M. Shionoya, J. Am. Chem. Soc. 2019, 141, 19342-19350; b) S. Diafa, D. Evéquoz, C. J. Leumann and M. Hollenstein in Synthesis and Enzymatic Characterization of Sugar-Modified Nucleoside Triphosphate Analogs, (Ed. N. Shank), Springer New York, New York, NY, 2019, pp. 1-13; c) T. Nakama, Y. Takezawa, D. Sasaki and M. Shionoya, J. Am. Chem. Soc. 2020, 142, 10153-10162. 
[21] a) K. Petrovec, B. J. Ravoo and J. Müller, Chem. Commun. 2012, 48, 11844-11846; b) J. Müller, D. Böhme, P. Lax, M. Morell Cerdà and M. Roitzsch, Chem. Eur. J. 2005, 11, 62466253.

[22] a) S. Johannsen, N. Megger, D. Böhme, R. K. O. Sigel and J. Müller, Nat. Chem. 2010, 2 , 229-234; b) D. Böhme, N. Düpre, D. A. Megger and J. Müller, Inorg. Chem. 2007, 46, 1011410119.

[23] N. Paul, V. C. Nashine, G. Hoops, P. M. Zhang, J. Zhou, D. E. Bergstrom and V. J. Davisson, Chem. Biol. 2003, 10, 815-825.

[24] P. Röthlisberger, F. Levi-Acobas, I. Sarac, P. Marliere, P. Herdewijn and M. Hollenstein, Org. Biomol. Chem. 2017, 15, 4449-4455.

[25] P. Röthlisberger, F. Levi-Acobas, I. Sarac, P. Marliere, P. Herdewijn and M. Hollenstein, J. Inorg. Biochem. 2019, 191, 154-163.

[26] N. Sandmann, D. Defayay, A. Hepp and J. Müller, J. Inorg. Biochem. 2019, 191, 85-93.

[27] S. Hensel, N. Megger, K. Schweizer and J. Müller, Beilstein J. Org. Chem. 2014, 10, 21392144.

[28] J. Ludwig and F. Eckstein, J. Org. Chem. 1989, 54, 631-635.

[29] S. Pochet and L. Dugue, Nucleosides Nucleotides 1998, 17, 2003-2009.

[30] M. Flamme, L. K. McKenzie, I. Sarac and M. Hollenstein, Methods 2019, 161, 64-82.

[31] a) A. C. Larsen, M. R. Dunn, A. Hatch, S. P. Sau, C. Youngbull and J. C. Chaput, Nat. Commun. 2016, 7, 9; b) S. Tabor and C. C. Richardson, Proc. Natl. Acad. Sci. U.S.A. 1989, 86, 4076-4080.

[32] a) B. Jash and J. Müller, J. Inorg. Biochem. 2018, 186, 301-306; b) M. Tasaka, K. Tanaka, M. Shiro and M. Shionoya, Supramol. Chem. 2001, 13, 671-675; c) D. U. Ukale and T. Lönnberg, Angew. Chem. Int. Ed. 2018, 57, 16171-16175; d) X. R. Guo, P. Leonard, S. A. Ingale, J. Liu, H. Mei, M. Sieg and F. Seela, Chem. Eur. J. 2018, 24, 8883-8892; e) N. Santamaria-Diaz, J. M. Mendez-Arriaga, J. M. Salas and M. A. Galindo, Angew. Chem. Int. Ed. 2016, 55, 6170-6174; f) Y. Takezawa, J. Müller and M. Shionoya, Chem. Lett. 2017, 46, 622633; g) H. Räisälä and T. Lönnberg, Chem. Eur. J. 2019, 25, 4751-4756.

[33] A. K. Vashishtha, J. Wang and W. H. Konigsberg, J. Biol. Chem. 2016, 291, 20869-20875. [34] a) F. Mani and G. Scapacci, Inorg. Chim. Acta 1976, 16, 163-166; b) T. Rüther, N. Braussaud and K. J. Cavell, Organometallics 2001, 20, 1247-1250; c) W. J. Eilbeck, F. Holmes, C. E. Taylor and A. E. Underhill, J. Chem. Soc. A. 1968, 128-132; d) Y. Wang, C.-T. He, Y.-J. Liu, T.-Q. Zhao, X.-M. Lu, W.-X. Zhang, J.-P. Zhang and X.-M. Chen, Inorg. Chem. 2012, 51, 4772-4778; e) J. J. Warren and J. M. Mayer, J. Am. Chem. Soc. 2008, 130, 2774-2776; f) C. W. Tsai, R. E. Kroon, H. C. Swart, J. J. Terblans and R. A. Harris, J. Lumin. 2019, 207, 454-459; g) A. Turek and M. Olczak-Kobza, J. Therm. Anal. Calorim. 1998, 54, 133-137; h) R. Curini, S. Materazzi and G. Dascenzo, Thermochim. Acta 1990, 164, 237-249; i) C. J. Serpell, J. Cookson and P. D. Beer, ChemistryOpen 2020, 9, 683-690.

[35] a) K. M. Pugliese, O. T. Gul, Y. Choi, T. J. Olsen, P. C. Sims, P. G. Collins and G. A. Weiss, J. Am. Chem. Soc. 2015, 137, 9587-9594; b) M. Hocek, Acc. Chem. Res. 2019, 52, 17301737.

[36] a) A. Simonova, I. Magriñá, V. Sýkorová, R. Pohl, M. Ortiz, L. Havran, M. Fojta, C. K. O'Sullivan and M. Hocek, Chem. Eur. J. 2020, 26, 1286-1291; b) P. Röthlisberger, F. LeviAcobas, C. J. Leumann and M. Hollenstein, Bioorg. Med. Chem. 2020, 28, 115487; c) O. A. Zasedateleva, S. A. Surzhikov, V. E. Shershov, R. A. Miftakhov, D. A. Yurasov, V. E. Kuznetsova and A. V. Chudinov, Bioorg. Chem. 2020, 99, 103829.

[37] a) S. Palluk, D. H. Arlow, T. de Rond, S. Barthel, J. S. Kang, R. Bector, H. M. Baghdassarian, A. N. Truong, P. W. Kim, A. K. Singh, N. J. Hillson and J. D. Keasling, Nat. Biotechnol. 2018, 36, 645-650; b) M. Welter, D. Verga and A. Marx, Angew. Chem. Int. Ed. 2016, 55, 10131-10135. 
[38] J. Balintová, M. Welter and A. Marx, Chem. Sci. 2018, 9, 7122-7125.

[39] A. Marx and K. Betz, Chem. Eur. J. 2020, 26, 3446-3463.

[40] a) I. Hirao, Y. Harada, M. Kimoto, T. Mitsui, T. Fujiwara and S. Yokoyama, J. Am. Chem. Soc. 2004, 126, 13298-13305; b) E. T. Kool, Curr. Opin. Chem. Biol. 2000, 4, 602-608; c) I. Singh, R. Laos, S. Hoshika, S. A. Benner and M. M. Georgiadis, Nucleic Acids Res. 2018, 46, 7977-7988.

[41] A. T. Krueger and E. T. Kool, Chem. Biol. 2009, 16, 242-248.

[42] F. Levi-Acobas, P. Röthlisberger, I. Sarac, P. Marlière, P. Herdewijn and M. Hollenstein, ChemBioChem 2019, 20, 3032-3040.

[43] J. C. Morales and E. T. Kool, J. Am. Chem. Soc. 1999, 121, 2323-2324.

[44] S. Matsuda, A. A. Henry, P. G. Schultz and F. E. Romesberg, J. Am. Chem. Soc. 2003, 125, 6134-6139.

[45] S. Brown, M. M. Lockart, C. S. Thomas, M. K. Bowman, S. A. Woski and J. B. Vincent, ChemBioChem 2020, 21, 628-631. 


\section{Entry for the Table of Contents}

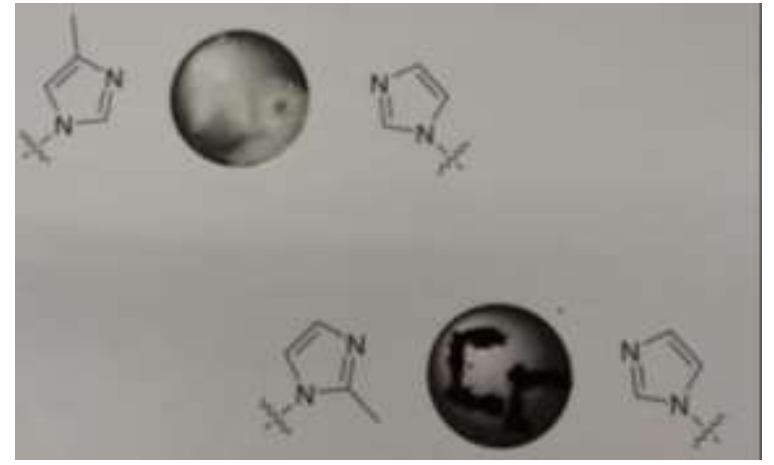

In the context of an expansion of the genetic alphabet with artificial metal base pairs we have explored the possibility of using nucleotides bearing methylated imidazole base surrogates. This methylation pattern improves silver-mediated base pair formation compared to the unmodified imidiazole nucleotide. We also have extended this approach to underexplored metal ions and observed the formation of a chromium-mediated metal base pair.

Institute and/or researcher Twitter usernames: @Hollensteinlab and @ GasserGroup 